QUADERNS DE FILOSOFIA VOL. II NÚM. 2 (2015): 95-I 35

ISSN: 234I-I4I 4 eISSN: 234I-3042 DOI: IO.7203/QFIA.2.2.7070

BARRY STROUD

UC Berkeley

\title{
L'autocomprensió i l'expectativa d'assolir l'objectivitat
}

Traducció de Francisco Javier Bilbao de las Heras, Marc Borràs Barberà i Carlos Fenollosa Esteve

Revisió de Sergi Rosell i Josep E. Corbí

"En aquestes conferències he tractat de ressaltar que, si tenim una explicació ferma i precisa de com pensem el món —i sobre el que hi percebem, hi sentim i hi creiem-, podem veure que I'única cosa que faria atractiu el 'subjectivisme' és la defensa d'una concepció molt restringida del contingut de les experiències i els sentiments que tenim al nostre abast. Amb la bellesa i la causalitat trobàrem que ni tan sols podíem identificar els sentiments o les experiències en qüestió sense tenir ja prèviament la idea de bellesa o de causalitat que apliquem al món en aquests mateixos judicis. Semblava que el 'subjectivisme' prometia més en el cas dels colors i dels valors. Però allò que creiem sobre els colors dels objectes del món semblava massa estretament implicat en la nostra comprensió de les percepcions de color perquè poguem considerar que aquestes percepcions són res més que sensacions de determinats tipus. I el fet de prendre certes consideracions com a raons per a actuar de determinada manera també semblava estar massa estretament implicat en què volem i com decidim actuar perquè puguem entendre les voluntats i els desitjos que tenim com a meres sensacions o sentiments que, en alguna mesura, ens menen a l'acció".

B. S. 


\section{Conferència I \\ EL subJECTIVISME}

En aquestes conferències, m'agradaria il.lustrar i intentar explicar, en termes molt generals, com el fet de plantejar un problema filosòfic des d'una posició determinada, o de tractar-lo d'una manera i no d'una altra, pot portar-nos a resultats molt diferents. Que un enfocament ens puga conduir a una solució satisfactòria, o fins i tot a l'expectativa raonable de trobar-ne una, depèn de l'origen real del problema, i d'això no podem estar segurs amb antelació, o en general.

D'una manera o altra, crec que els problemes filosòfics que tinc presents resultaran coneguts per a la majoria de vostès. Són problemes molt generals que es plantegen en reflexionar sobre el món on vivim i les maneres que tenim d'experimentar-lo i pensar-lo. Volem concebre'ns com a part del mateix món en què creiem. Però trobe que assolir una comprensió plenament satisfactòria mitjançant aquesta via d'autocomprensió presenta certes dificultats. Tot i això, crec que és una manera de concebre'ns a què aspirem molts de nosaltres. Amb "concebre'ns" o "autocomprensió" no faig referència a la classe de comprensió que cadascun de nosaltres pot tenir d'ell mateix: la meua autocomprensió de mi, la seua comprensió de vostè i així successivament. Pot ser que aquest siga un tema massa personal de què tractar en una conferència pública. Faig referència a l'autocomprensió general de la posició que tots nosaltres ocupem com a éssers humans en un món comú.

Tots tenim una concepció molt rica i complexa de com són les coses al món: què hi ha i què no hi ha, què importa més i què importa menys, què és raonable fer i què es raonable evitar. Per mitjà de la reflexió filosòfica tractem d'entendre la relació que hi ha entre l'enorme conglomerat que conforma la nostra manera de pensar i de respondre al món, d'una banda, i les coses tal com realment són en aquest món, de l'altra. Sabem que hem arribat a tenir la concepció del món que tenim només perquè vam créixer i interactuar al mateix món al qual fan referència els nostres pensaments, creences i sentiments. ${ }^{1}$ Sabem que responem al món de la manera com ho fem, en part, per com és el món en realitat i com ens afecta i, en part, per com som nosaltres i com responem de manera natural als estímuls d'aquest món.

Això sembla conduir-nos, amb naturalitat, a una pregunta molt general: “En quina mesura allò que pensem, creiem i sentim sobre el món reflecteix,

\footnotetext{
${ }^{1}$ Hem decidit traduir "feeling" de manera preferent per "sentiment" i optar sols per "sensació" en els contextos on hi ha un contrast amb "sentiment".
} 
fil per randa, com són les coses en aquest món, i en quina mesura expressa solament alguna cosa sobre nosaltres i les nostres maneres de respondre a aquest món, i no quelcom que és així al món en sí mateix?” La pregunta té un ressò particularment filosòfic. En plantejar-nos-la, volem sospesar la magnitud de la contribució distintivament humana a la nostra concepció general del món. Volem distingir entre els aspectes de la nostra concepció que tenen un origen humà i les coses que creiem que ens arriben de quelcom que està més enllà $\mathrm{i}$ que és independent de nosaltres. Si això fóra possible, potser ens adonaríem que moltes coses que creiem depenen de la nostra manera de pensar, de sentir i de respondre-hi, mentre que gran part de la resta d'allò que creiem és totalment independent de nosaltres i de les nostres reaccions.

Establir una distinció general com aquesta, d'una manera global, és una empresa molt ambiciosa. Però si poguérem dur-la a terme, o si més no ferhi alguns progressos, potser tindríem la possibilitat d'assolir una comprensió objectiva satisfactòria de nosaltres mateixos i de les nostres creences en relació amb la realitat del món. Podríem veure que algunes de les nostres creences sobre el món no copsen res respecte a com és aquest món amb independència de com el pensem i el sentim. Molts filòsofs, així com molts altres que no són filòsofs, sembla que pensen que, en àrees importants de la vida humana, ja hem assolit aquesta mena de coneixement sobre nosaltres mateixos en relació amb el món que ens envolta.

Afirmar que la qüestió rau en com, o en quina mesura, la nostra concepció del món coincideix amb el món en si mateix ens pot fer pensar que es tracta d'una qüestió relativa al coneixement o a la fiabilitat de les nostres creences: a si tenim bones raons per a continuar creient allò que creiem sobre el món. Per descomptat, aquesta qüestió epistemològica ha estat una de les principals preocupacions de la filosofia, però les preguntes que vull fer paleses ací no estan directament relacionades amb el coneixement com a tal. Fins i tot si no tenim cap dubte, o fingim de moment no tenir-ne cap, respecte a la veritat d'allò que creiem o pensem que sabem, encara així ens podríem preguntar, amb esperit filosòfic, què és allò que hi ha al món que "fa" vertaderes les coses en què creiem, si és que són vertaderes. Podríem formular la pregunta així: Quina cosa hi ha al món "en virtut de la qual" les coses que creiem són veritables, si és que en efecte ho són? O, "a què equival" o "en què consisteix" allò que fa veritables les coses que realment creiem? Què "constitueix" la veritat de les coses que creiem? $\mathrm{O}$, com ha de ser el món perquè les coses que creiem sobre aquest món siguen veritat?

Aquestes són preguntes abstractes i una mica fosques. Potser puga ferles més terrenals, i fer més clara la idea del que està en qüestió, tot començant amb un exemple senzill. Tots creiem que certes coses del món són boniques 
o, si més no, més boniques que d'altres. Totes les cultures o societats semblen considerar certes coses com a més belles que d'altres, tot i que els judicis sobre coses particulars difereixen àmpliament d'una cultura o societat a una altra. Però tots hem sentit la dita "La bellesa es troba únicament a l'ull de qui mira". Entenc aquesta dita com una observació filosòfica molt general sobre la bellesa. Sembla que ens diga alguna cosa sobre la "naturalesa" de la bellesa: sobre què és realment la bellesa o quin es el seu "estatus" real. Aquesta dita diu que la bellesa d'una cosa es troba només en les nostres reaccions a la cosa, i no en res que pertanya a l'objecte tal com és amb independència de nosaltres i de les nostres reaccions.

Aquesta observació no diu simplement que la gent pensa que les coses són belles perquè aquestes coses els afecten de certa manera. Això és veritat de gairebé tot allò que creiem. Per exemple, creiem que alguns objectes són rodons o que alguns objectes són molt pesats només perquè aquests objectes ens afecten de certa manera. Però aquests objectes seguirien sent rodons o pesats tant si afectaren els perceptors d'una manera determinada com si no. Amb la bellesa, si l'entenem d'aquesta manera, això no és així. Segons aquest plantejament, quelcom que pertany a les reaccions dels "observadors" de l'objecte passa a formar part d'allò mateix que la gent creu quan creu que un objecte és bell. Si la gent no fóra afectada de la manera com és afectada pels objectes que consideren bells, aquests objectes simplement no serien bonics. Si els perceptors no reaccionaren d'unes maneres específiques als objectes, si no hi obtingueren certs tipus d'experiències, no hi hauria cap objecte bell, encara que el món restara tal com és ara. I, per descomptat, tampoc no hi hauria objectes lletjos al món.

Així, en aquest cas, la qüestió no és la de si podem saber que certes coses són boniques, sinó la de saber en què consisteix, o podria consistir, ser bonic: què és el que hi ha al món, o hi podria haver, en virtut de la qual cosa quelcom és bell. Molta gent accepta aquesta concepció popular de la bellesa; potser molts de vostès tendeixen a acceptar-la. Però, si hi creus, per què ho fas? Quin fil argumentatiu et mou a creure que la bellesa es troba $o$ no a l'ull de l'observador? Aquest és el tipus de pregunta en què vull centrar-me: no sols en la qüestió de si la bellesa es troba o no a l'ull de qui mira, sinó també en la de quins tipus de consideracions podrien comptar a favor de creure que efectivament s'hi troba i de quina manera.

Un fet que pot semblar important és el desacord generalitzat que existeix sobre la bellesa de les coses particulars. Fins i tot dins d'una societat o tradició, i molt més entre diferents cultures o períodes històrics, la gent sembla diferir molt en relació amb la bellesa de determinades coses. Però, ¿̇les discrepàncies de la gent sobre la bellesa impliquen que, en realitat, no hi ha res sobre el que puguen estar d'acord o en desacord? Més complex encara és saber sobre què 
discrepen exactament els qui no es posen d'acord sobre la bellesa. Quina és, exactament, la pregunta a què donen respostes diferents?

No vull negar que hi haja desacord, però no crec que la clau de la qüestió estiga sols en el desacord. Encara que hi haguera un acord ampli respecte de la bellesa de certes coses, crec que la gent continuaria trobant molt raonable la idea que la bellesa es troba únicament a l'ull de l'observador. Una de les raons d'això, crec jo, és que els nostres judicis relatius a la bellesa no són una cosa respecte de la qual puguem ser completament neutrals o indiferents. Si no tinguérem preferències o inclinacions sobre una cosa determinada, si això no ens interessara o ens atraguera més que la majoria d'altres coses, si no ens emocionara ni ens disgustara, ni ens provocara una reacció distintiva, ¿podríem considerar aquesta cosa bonica o àdhuc lletja? Sembla que tenir certes actituds o sentiments és essencial per a poder considerar bonica qualsevol cosa. Però això sembla que ens condueix a incloure'ns, a "nosaltres" i a les nostres actituds o sentiments, en els judicis relatius a la bellesa que fem. Hom suggereix que la bellesa que atribuïm a les coses, d'alguna manera, procedeix de nosaltres mateixos, de les actituds dels "observadors", i no, com podríem suposar "ingènuament”, d'un món que conté objectes que són bonics independentment de com nosaltres hi reaccionem.

Crec que la idea segons la qual la bellesa es troba només a l'ull de l'observador és un bon exemple de la classe de concepcions filosòfiques que vull considerar, atès que ens porta a pensar que les nostres experiències, els nostres sentiments o les nostres actituds semblen estar directament involucrats en les coses que creiem sobre el món que ens envolta. Aquesta mateixa idea està darrere dels intents de comprendre altres aspectes generals de la nostra concepció del món. Per exemple, en l'antiga Grècia, i després, amb més força, en l'Europa del segle Xvir, es defensà que els colors, els sabors i les olors que creiem que tenen les coses que ens envolten depenen tan sols dels perceptors i no, en part, del món independent. Segons Demòcrit, per exemple, tot allò que hi ha al món són petits àtoms físics que es mouen amunt $\mathrm{i}$ avall en el buit. Nosaltres també estem fets d'àtoms i, quan alguns dels àtoms que ens envolten afecten alguns dels àtoms que ens conformen, arribem a percebre colors, sabors i olors. La idea és que els colors, els sabors i les olors que experimentem no existirien si el món no ens afectara com ho fa, però les experiències que tenim quan això s'esdevé no són les percepcions de cap color, sabor o olor que pertanyen a alguna cosa que és part d'una naturalesa independent de nosaltres. En realitat, tot allò que s'esdevé al món independent són interaccions d'àtoms incolors, insípids i inodors amb altres àtoms del mateix tipus.

Galileu va expressar essencialment la mateixa idea 1.800 anys després. "Traieu els ulls, les orelles i els nassos de tots els animals que viuen", va dir, i hi 
continuarà havent objectes amb forma, mida i moviment, però els colors, els sons i les olors de les coses seran "aniquilats". L'existència mateixa d'aquestes propietats depèn de les reaccions dels perceptors. Com en el cas de la bellesa, podríem dir que els colors, els sabors i les olors de les coses es troben només a l'ull, l'orella o el nas de l'observador. No hi ha colors, sabors o olors enlloc més.

Moltes persones troben convincent aquest punt de vista. Un cop més em pregunte què és allò que sosté aquesta idea. I, d'acord amb quin raonament? Els colors, els sabors i les olors de les coses són, sens cap mena de dubte, una cosa que percebem. I no es pot negar que, si s'eliminen els mecanismes perceptius de tots els animals, cap animal no percebria cap mena de color, sabor o olor. Però si cap d'ells poguera percebre'ls, jjustificaria això que els objectes deixarien de tenir colors, sabors o olors? Fet i fet, si tots els mecanismes de percepció foren eliminats, ningú no podria percebre les formes, les mides o els moviments de cap objecte, però això no significaria que els objectes al món no tindrien realment cap forma, mida o moviment. Només significaria que ningú no percebria les formes, les mides i els moviments d'aquests objectes. Per què hauria de ser distint en el cas dels colors, els sabors i les olors dels objectes que percebem? Per què es pensa que aquestes propietats serien "aniquilades" per complet si ningú no fóra capaç de percebre-les?

Crec que allò que fa que semble tan raonable negar la realitat independent dels colors, els sabors i les olors de les coses és la idea segons la qual la nostra percepció d'aquestes qualitats no és, en realitat, més que un tipus distintiu de sensacions o impressions. Igualment, el dolor és també un tipus distintiu de sensació. Però quan ens punxem el dit amb una agulla i sentim dolor no suposem que el dolor que sentim es troba d'alguna manera a l'agulla o que aquesta pateix alguna mena de dolor que li és propi. Expliquem per què sentim dolor sense suposar res tan absurd com això. Els dolors són només sensacions; no pertanyen als objectes inanimats.

Si la percepció dels colors, els sabors i les olors de les coses fóra només una manera de tenir unes classes determinades de sensacions, aleshores els colors, els sabors i les olors que percebem serien només una cosa que percebem i no quelcom que pertany als objectes que causen aquestes percepcions. La transmissió de la llum, les vibracions de les ones sonores, l'estimulació de les fosses nasals - $\mathrm{i}$ els seus respectius efectes sobre el nostre cervell- podrien constituir tot el que necessitem per a explicar la manera com el cervell aconsegueix tenir sensacions. Així ho fem amb els dolors, i, si entenem la nostra percepció de colors, sabors i olors de la mateixa manera — com una simple qüestió de tenir unes sensacions específiques-, tindrem el que sembla ser un suport real de la idea que afirma que les qualitats quotidianes de les coses que 
ens envolten també depenen de nosaltres, els "perceptors", i no dels colors, els sabors o els olors de qualsevol objecte del món independent.

Crec que aquest plantejament proporciona una concepció definida de la nostra experiència perceptiva d'aquestes qualitats. I crec que és una concepció molt limitada i austera d'aquesta experiència. En sentit estricte, segons aquesta idea, no veiem mai la rojor d'una poma que està davant nostre ni olorem l'aroma d'una flor que tenim a les mans. Veiem el color roig i li atribuïm, en el pensament, aquest color a la poma. Olorem una certa flaire agradable i li atribuïm aquesta olor a la flor. Però la idea és que, en tenir aquests pensaments, anem més enllà d'allò que, estrictament parlant, se'ns mostra en la nostra experiència perceptiva. Des d'aquesta perspectiva, del que més consciència tenim, en aquestes experiències perceptives, és de coses de què també podríem ser conscients encara que no hi haguera res al món que tinguera alguna de les qualitats de què som conscients. Segons aquesta manera de veure les coses, només som conscients del caràcter específic de les experiències sensorials, però de no res que estiga més enllà d'aquestes experiències.

Aquesta concepció limitada del que copsem amb l'experiència perceptiva ha estat filosòficament molt influent. Un dels seus defensors més ferms va ser David Hume, qui la va aplicar a un camp molt més ampli que el dels colors, els sabors i les olors. Hume creia que totes les nostres idees, i per tant totes les maneres com pensem el món, eren fruit de sensacions o impressions d'aquest tipus. En conseqüència, tots els nostres pensaments i creences només es poden entendre resseguint-ne el rastre cap enrere fins arribar al seu origen en les impressions, les sensacions o els sentiments. Hume pensava que fins i tot la idea de causa i efecte — que considerava essencial no sols per a la ciència física, sinó també per a pensar un món independent- s'ha de concebre com a derivada de les impressions que rebem en la nostra experiència perceptiva immediata. Afirmava que, amb la idea de causa i efecte, "contribuïm" nosaltres mateixos a bastir la nostra concepció del món, ja que la trobem en la nostra experiència perceptiva, però no perquè percebem mai una cosa com a causa d'una altra. Així que, per a Hume, la relació de causa i efecte en què creiem té, si fa no fa, la mateixa relació amb allò que és realment així al món independent que la que tenen, sota el punt de vista que estic descrivint, la bellesa, els colors, els sabors $\mathrm{i}$ les olors de les coses.

Hume afirmava que fonamentalment copsem la idea de causalitat en veure que ocorre una cosa i que, tot seguit, n'ocorre una altra. Una bola de billar en colpeja una altra; la segona bola es mou. Hume creu que, en aquest cas, en realitat només veiem els esdeveniments individuals, i no cap connexió, vincle o dependència entre esdeveniments. Experimentem sols la seqüència dels dos esdeveniments diferents. Però, després d'haver vist que seqüències com 
aquestes es repeteixen una i altra vegada, la nostra ment acaba per esperar una cosa del segon tipus sempre que veiem una cosa del primer tipus. Que tinguem una creença com aquesta és un fet que parla sobre nosaltres; sobre com funciona la nostra ment. Generem determinades expectatives quan, en la nostra experiència, certs tipus de percepcions s'han seguit regularment d'uns altres tipus de percepcions.

Hume pensa que quan aquest tipus de regularitat ha estat present en la nostra experiència i percebem una cosa del primer tipus, no solament esperem una cosa del segon tipus, sinó que també tendim a pensar que alguna cosa del segon tipus ha d'ocórrer des del moment en què una cosa del primer tipus ha ocorregut. Ens fem la idea d'una connexió entre els dos esdeveniments — d'una connexió necessària entre esdeveniments- $\mathrm{i}$ arribem a creure que els dos esdeveniments estan connectats com a causa i efecte. El fet que tots coincidim a l'hora de pensar d'aquesta manera és, simplement, quelcom que parla sobre nosaltres, sobre com funciona la nostra ment. Realment, no hi ha cap relació de causa i efecte entre els dos esdeveniments que percebem. El segon esdeveniment no depèn de si el primer s'ha esdevingut. Només arribem a creure que ho fa per quelcom que passa en les nostres ments quan ens trobem amb aquest tipus de seqüències semblants a les percepcions que experimentem. Estem fets de tal manera que el nostre pensament passa facilment de la idea d'una cosa a la idea del que trobem que és el "concomitant habitual" de les coses d'aquest tipus; i tenim una certa sensació o "impressió interna" d'aquesta transició mental d'una a l'altra. Aquesta "impressió interna” és només una cosa que sentim, però ens porta a formar-nos una idea determinada — una idea de connexió necessària- i arribem així a creure que les coses del món estan connectades necessàriament o per causes i efectes. Tot el que fa referència a com pensem, i a com ens veiem forçats a pensar que ho fem, només s'explica per determinades coses que són veritats sobre nosaltres i sobre la manera com responem a la nostra experiència, no per res que estiga causalment connectat amb qualsevol altra cosa en el món. Així, segons la idea de causalitat de Hume, i també, com ja hem vist, en els casos de la bellesa, i dels colors, els sabors i les olors de les coses, allò que copsem en l'experiència perceptiva no té més relació directa amb allò que és al món que ens envolta que la que té el dolor que sentim amb l'agulla que ens ha causat aquesta sensació. No és necessari que existesca res al món per a explicar com arribem a creure que hi és.

Hume emfatitza que, en la causalitat, "sobretot, la necessitat és una cosa que existeix en la ment, no en els objectes". ${ }^{2}$ No vol dir que hi haja connexions

${ }^{2}$ D. Hume, Tractat de la naturalesa humana; traduït directament de l'edició anglesa de SelbyBigge (Oxford, I958), 165. 
de causa i efecte entre les coses de la ment i no entre cap altre tipus d'objectes. Vol dir que no hi ha connexions necessàries o causals entre les coses en cap part del món independent. Si creiem que existeixen és pel que ocorre en la nostra ment quan tenim certs tipus d'experiències. La idea és que no cal que existesquen esdeveniments que estiguen, en realitat, causalment connectats per tal d'explicar per què tots creiem que certs esdeveniments ho estan. La nostra constitució i les nostres respostes mentals naturals a les coses són suficients per si mateixes per a explicar que creguem que hi ha relacions causals al món. No cal que la creença siga veritable perquè puga explicar per què hi creiem.

Si girem la vista cap als exemples considerats fins ara, probablement molts de vostès concordaran que la bellesa es troba únicament a l'ull de l'observador, i potser també que els sabors i les olors, i potser fins i tot els colors, de les coses, depenen del tipus de percepcions que els observadors tenen o podrien tenir d'aquestes coses. Però, ¿̇troben igualment plausible que creure que una cosa és causa d'una altra, o no creure-ho, depenga també de quin tipus de percepcions, nosaltres els "observadors", tenim o podríem tenir d'aquestes coses? Aquest raonament sobre la causalitat pot semblar difícil d'acceptar, però el tipus d'argument utilitzat ací és el mateix que als altres casos, aparentment més plausibles.

L'argument afirma que si determinades experiències sensorials, a més dels nostres mecanismes mentals, són suficients per si mateixes per a explicar com ens formem les creences que estem considerant, aleshores seria possible tenir totes les experiències sensorials que tenim tant si el món continguera alguna de les coses que creiem com si no les continguera. Si això fóra així, no hauríem de suposar que les coses del món posseeixen realment cap d'aquestes propietats que creiem. Si les nostres creences sobre les coses pogueren explicar-se d'aquesta manera, llavors la bellesa, els colors, els gustos i les olors de les coses, i les connexions causals que creiem que s'escauen entre les coses del món, haurien estat, en paraules de Galileu, "aniquilades". Haurien estat abolides del món tal com concebem que és, en tant que independent de totes les nostres percepcions del món.

Vull considerar ara una nova aplicació d'aquesta mateixa manera de reflexionar sobre nosaltres i sobre el món, que també sembla tenir el suport de la mateixa concepció restringida de l'experiència perceptiva i el mateix tipus de conseqüències que hem vist abans. Però aquesta aplicació de la idea no té només un interès purament teòric o filosòfic, sinó que també pot tenir conseqüències morals, socials i polítiques ben reals. Vull referir-me a la consideració que, com s’acostuma a dir, "tots els valors són subjectius".

Fins ara no he utilitzat la paraula "subjectiu". És una paraula especialment esmunyedissa i cal tenir cura en fer-la servir. Crec que els casos que hem 
considerat fins ara poden ser útils com a guia. Dir que la bellesa, el color, el gust o la causalitat d'una cosa és "subjectiva" és dir que la bellesa, el color, el gust o la causalitat de les coses només depenen de quin tipus d'experiències, sentiments o reaccions tenen, sota determinades circumstàncies específiques, els subjectes perceptors de la cosa. En aquest punt, sembla una obvietat que les nostres avaluacions de les coses com a bones o dolentes, admirables o deplorables, desitjables o indesitjables, etc., són "subjectives" en aquest sentit. Sembla ser una creença general que cap d'aquestes valoracions és independent de les reaccions, els sentiments, les actituds o els interessos de certs perceptors, agents $\mathrm{o}$ altres subjectes. Però els judicis avaluatius són a la base d'allò que la gent fa o deixa de fer. Així que comprendre adequadament la qüestió de l'avaluació de les coses és fonamental per a tota mena de vida personal, social i política, més enllà dels límits de la filosofia mateixa.

Aquesta és una pregunta sobre nosaltres mateixos i sobre la nostra manera d'actuar al món en què sabem que vivim. ¿Com podem resoldre aquestes qüestions avaluatives? Des dels casos més trivials, com quan pensem a fer certa cosa i després ens decidim a fer-la, fins als casos més importants, com quan hem d'avaluar les nostres accions i les dels altres o defensar determinats acords socials o polítics, cal que trobem alguna base per a preferir o aprovar una manera d'actuar i no d'altres. Decidir, triar o avaluar requereix trobar alguna cosa més en favor d'un tipus de cosa o acció que en favor d'altres. Com ho fem, això? Un cop més, podem traure profit de l'obra de l'incomparable David Hume, encara que no compartim els seus punts de vista. Hume ha donat una de les expressions més vívides, provocadores $i$, per descomptat, influents d'una concepció "subjectivista" de l'avaluació, la decisió i l'acció. Hume il.lustra la nostra situació a l'hora d'avaluar una acció com a bona o dolenta, virtuosa o viciosa, de la manera següent:

Preneu qualsevol acció que considerem un vici: l'assassinat premeditat, per exemple. Examineu-la amb tot detall i tracteu de veure si es pot trobar algun fet $\mathrm{o}$ existència real d'això que anomenem vici. Des de qualsevol punt de vista que l'examineu, només trobareu certes passions, motius, volicions i pensaments. No hi ha cap altra qüestió de fet en aquest cas. El vici sempre se us escaparà, si considereu únicament l'objecte. Mai no el podreu trobar si no és que dirigiu la reflexió al vostre interior i trobeu un sentiment de desaprovació, que sorgesca en vosaltres, envers aquesta acció. Heus ací una qüestió de fet; però és un objecte del sentiment, no de la raó. Es troba en nosaltres, no en l'objecte ${ }^{3}$

${ }^{3}$ Tractat, ed. cit., 468-9. 
Aquest sorprenent passatge traça, en essència, un paral-lelisme amb els exemples que ja hem considerat. La "maldat" que atribuïm a un acte d'assassinat premeditat, diu Hume, "es troba en nosaltres, no en l'objecte", tal com dèiem de la bellesa "que es troba únicament a l'ull de l'observador" i de la causalitat que existeix "només en la ment i no en els objectes". Per aclarir el raonament, Hume hi afegeix:

El vici i la virtut, per tant, es poden comparar als sons, els colors, la calor i el fred, que d'acord amb la filosofia moderna no són qualitats dels objectes sinó percepcions en la ment ${ }^{4}$

Les "percepcions en la ment", a les quals Hume fa referència, són l'origen de tots els nostres judicis relatius al vici i a la virtut, al bé i al mal; són sensacions o sentiments, no pensaments ni creences sobre que una cosa o altra siga així al món. No són detectables pel pensament o pel raonament, sinó només pel sentiment, en les circumstàncies apropiades. "La moral, per tant, és més pròpiament sentida que jutjada”, conclou Hume. ${ }^{5}$

Quan Hume diu que les avaluacions o valoracions de la moral són una qüestió de sentiment més que de pensament o raó no és simplement perquè s'adone que ell mateix té aquests sentiments o perquè altres persones també els tinguen. Si Hume té raó, tots tenim aquests sentiments. El seu punt de vista és que, si no tinguérem el tipus de sentiments que tenim, no existiria la moral. És en aquest sentit que "la moral... és més pròpiament sentida que jutjada".

Hume dóna suport a aquesta conclusió amb un argument que sembla molt convincent. El primer pas del raonament diu que valorar una cosa més que una altra, creure que és millor que l'altra, és tenir un determinat tipus d'actitud "pràctica" o "activa" envers la cosa preferida. Jutjar que un curs d'acció és millor que un altre implica subscriure, donar suport, preferir o voler aquest curs d'acció més que un altre. Subscriure'l és tenir la inclinació o estar motivat a actuar d'una manera determinada; no necessàriament fer-ho, o fins i tot decidir fer-ho, sinó, si més no, estar inclinat o tenir una actitud favorable a fer-ho si es presenten les circumstàncies adequades. Una persona que romanguera completament indiferent davant de totes les possibilitats que se li presenten $\mathrm{i}$ no valorara cap curs d'acció més que cap altre, o no tinguera cap preferència o inclinació a favor de qualsevol de les opcions disponibles, mai no passaria a l'acció. Una persona així restaria completament indiferent i, per tant, ni tan sols seria un agent potencial. Podria mantenir moltes creences relatives a allò

${ }^{4}$ Tractat, ed. cit., 469.

${ }^{5}$ Tractat, ed. cit., 470. 
que Hume anomena "qüestions de fet", però, si mantinguera aquestes creences sense cap actitud "pràctica" o "activa" envers qualsevol de les possibilitats que se li obrin, mai no faria res.

Els agents, efectius o potencials, no són completament indiferents en aquest sentit: volen determinades coses, les busquen, les prefereixen o s'inclinen envers aquestes coses més que envers d'altres, i aquestes actituds els menen a actuar com actuen. El segon i decisiu pas en el raonament de Hume diu que les úniques necessitats o desitjos o preferències que poden dur a una persona a actuar són les sensacions o els sentiments, o allò que Hume anomena en general "passions". Pensar o raonar o descobrir la veritat o la falsedat, sense l'“addició" de qualsevol necessitat o desig o inclinació en una direcció o una altra, mai no podrà produir una acció. Sense necessitats o desigs i, també per a Hume, sense les sensacions o els sentiments, no existirien les accions intencionals.

És clar que Hume sap que les persones, de vegades, actuem per consideracions morals sobre allò bo o dolent, sobre la virtut o el vici. Ens comportem d'una determinada manera, perquè pensem que és bo, correcte o el millor que podem fer. Com que aquestes consideracions, de vegades, ens mouen a actuar, i com que el pensament i el raonament, per si mateixos, mai no ens podrien moure a actuar, se'n segueix que els judicis avaluatius de la moral no naixen, i no poden nàixer, únicament del pensament i el raonament. Si seguim les exigències de la moral, com la resta de coses que fem, és perquè tenim certes volicions i desitjos. I, d'acord amb Hume, aquestes volicions i aquests desitjos són sols sensacions, sentiments o passions. Són l'únic tipus de coses que poden menar a una persona a actuar. Les avaluacions i les accions intencionals de tota mena, no tan sols les morals, són qüestió de sentiment, no de raó.

Aquests sentiments o sensacions que ens porten a actuar fan que determinats objectes o accions siguen preferibles o desitjables per a un agent. Els sentiments "donen" als objectes, o a les accions a què es dirigeixen, l'únic valor que aquestes accions poden tenir per a un agent potencial. Si un agent no tinguera la necessitat o el desig d'un determinat objecte, aquest no tindria més valor per a aquesta persona que qualsevol altre objecte o acció. Així que ni els objectes ni les accions tindrien cap valor si ningú no hi responguera amb les sensacions o els sentiments apropiats.

Crec que en aquesta idea que considera les volicions i els desitjos com a sensacions o sentiments es troba el veritable origen del fort atractiu que té l'opinió segons la qual la moral, i tots els altres valors, són "subjectius" i depenen de les sensacions i els sentiments dels agents humans. Aquesta és la idea que s'ha mantingut des d'aquest punt de vista durant la seua llarga història i que explica la força que té avui dia. Això vol dir que qualsevol valor que, per a 
qualsevol persona, tinga una cosa ha de "raure" d'alguna manera tan sols en els sentiments o les sensacions reals o possibles d'éssers humans actius i no, doncs, en res que siga al món amb independència de tots aquests sentiments.

En reflexionar sobre nosaltres mateixos i sobre la nostra posició, tot arribant d'aquesta manera a una concepció "subjectivista" general d'aquestes característiques del món, ens situem a nosaltres mateixos i als nostres sentiments i reaccions al bell mig del relat. Es considera, doncs, que aquests sentiments $\mathrm{i}$ reaccions, d'alguna manera, formen part de les coses que creiem que són belles, que tenen un color o un sabor determinat, que estan causades d'alguna manera, o que són bones o dolentes. Segons aquesta posició, res no resultaria bonic, ni tindria color, seria saborós, estaria causat o seria bo o dolent, si la gent no responguera a les coses de determinades maneres. Això, per tant, sembla donar a entendre que moltes de les nostres creences - fins i tot les creences que són fonamentals per a la vida humana - no descriuen res que siga realment així al món, de manera completament independent a nosaltres. Sota aquest punt de vista, si allò que creiem quan creiem que les coses són belles, de color, causades, bones o dolentes és veritable, llavors hem d'entendre que aquestes creences tenen un aspecte "subjectiu" que no és eliminable. No s'escaurien al món tal com és o com seria amb total independència de les experiències, emocions o sensacions humanes.

Moltes persones troben molt persuasiva aquesta manera d'entendre'ns a nosaltres mateixos. Alguns mantindrien que, en realitat, no hi ha cap alternativa a concebre'ns d'aquesta manera si, en definitiva, ens considerem observadors i actors al món. Però crec que només podem trobar totalment satisfactori aquest punt de vista si entenem el que són realment aquests sentiments que, se’ns diu, juguen un paper tan important en la nostra concepció del món. Què són exactament aquests sentiments que tenim quan trobem que una cosa és bella? Presumiblement, són sensacions agradables o positives, però no tota sensació agradable és una reacció a la bellesa. ¿És possible concretar la rellevància específica d'aquests sentiments respecte de la bellesa sense esmentar la bellesa que aquests sentiments aparentment ens menen a atribuir a un objecte que considerem bell? I, quines són les característiques específiques de les sensacions o impressions que es consideren essencials per a la formació de la nostra creença que quelcom és verd, roig o blau? ¿Poden identificar-se aquestes percepcions sense especificar els colors dels objectes que creiem que ens donen aquestes impressions? I, què ocorre amb la causalitat? Quina és exactament la impressió que tenim quan veiem que el moviment d'una bola de billar causa el moviment d'una altra? ¿Hi ha alguna manera neutral, asèptica i que no siga causal per a descriure el fenomen? I, com és exactament la sensació o el sentiment que ens produeix un acte que considerem viciós o dolent? Cal suposar que un senti- 
ment negatiu o desagradable, però no tots els sentiments desagradables ens fan jutjar una cosa com a viciosa o dolenta.

Així doncs, el problema general consisteix a identificar les experiències o els sentiments rellevants de tal manera que puguem explicar com obtenim les creences que segons aquest plantejament ens formem dels objectes que percebem. Aquesta dificultat del "subjectivisme" pel que fa a la moral la va expressar de manera commovedora Bertrand Russell, que un cop va confessar:

No veig la manera de refutar els arguments a favor de la subjectivitat dels valors ètics, però em trobe incapaç de creure que tot allò que hi ha de dolent en la crueltat sense sentit és que a mi no m'agrada

Russell va sentir la insatisfacció del "subjectivisme" tal com l'hem tractat d'entendre. Sentia que no podia abandonar aquesta posició, però tampoc va arribar a resoldre la insatisfacció que li produïa. El problema és que qui considera que la crueltat gratuïta és dolenta no ho fa simplement perquè no li agrade, sinó perquè creu que és dolenta. El "subjectivisme" ha d'explicar què pensa una persona quan considera que certa cosa és injusta, viciosa o dolenta, i de quina manera està connectat el que pensa amb el que sent. Pensar que una cosa és dolenta no implica sols el desgrat, la desaprovació o l'avaluació negativa d'un tipus específic. Una dilucidació plenament satisfactòria del "subjectivisme" dels valors ha d'aportar una explicació convincent d'aquesta actitud específica, i ho ha de fer únicament en termes de sentiments. El mateix problema sorgeix en relació amb les percepcions i les reaccions que, es diu, estan involucrades en els altres tipus de creences que hem considerat. Aquest és un problema fonamental del "subjectivisme" que no crec que haja estat resolt.

Però, fins i tot si aquesta mena d'experiències o sentiments característics pogueren ser especificats amb precisió cas per cas, es plantejaria la qüestió addicional de quin paper podem entendre que juguen aquestes reaccions i sentiments en la nostra concepció del món. ¿Com contribueixen exactament a allò que creiem en creure el que creiem? Quan diem que una cosa que observem és bella, ¿estem simplement descrivint la sensació que ens produeix, o realitza la nostra reacció una funció diferent en allò que pensem? Si tenim una sensació de desaprovació en considerar que un determinat acte és maliciós o dolent, ¿sentim certa cosa que, d'alguna manera, "projecta" aquest sensació nostra a l'acció? Si és així, com ho fem? ¿O tan sols creiem que gairebé tothom té, o hauria de tenir, un sentiment similar de desaprovació envers aquest fet, si pren en consideració la qüestió? Una estratègia que sembla prometedora és la de no concebre els anomenats judicis avaluatius com a creences sobre certa cosa del món, sinó només com a expressions de sentiments o actituds que mantenim 
envers determinades coses o accions. Però se'ns plantegen, altra vegada, les preguntes de quins són aquests sentiments i com els expressem. Donar respostes convincents a totes dues preguntes és essencial per a la justificació del "subjectivisme".

Reprendrem aquestes preguntes més endavant. Però crec que podem dir de moment que, independentment d'allò que puguem pensar sobre els assoliments d'aquest immens projecte, si aquesta àmplia estratègia "subjectivista" poguera arribar, d'alguna manera, a funcionar, sembla prometre'ns un tipus de comprensió de nosaltres mateixos i de les nostres creences que crec que és la que busquem. Aspirem a un coneixement general i integral de la relació que mantenim nosaltres i la nostra concepció del món amb el món en si mateix. Si en la nostra concepció del món poguérem aconseguir separar, d'una banda, tot el que obtenim del món mateix i, de l'altra, la "contribució" que nosaltres fem en forma de reaccions "subjectives", aleshores estaríem en condicions d'entendre com es combinen aquests dos ingredients separats, a partir de diferents fonts, amb la finalitat de conformar una concepció del món única, unificada $\mathrm{i}$ intel-ligible. No es pot esperar que aquest resultat arribe demà, però sembla que, si poguérem realitzar aquesta gesta, o fins i tot avançar en aquesta direcció, ens estaríem acostant a una comprensió per fi satisfactòria de la relació entre nosaltres —inclosa la nostra concepció del món-i les coses tal com són realment al món on vivim.

\section{Conferència II EL PENSAMENT OBJECTIU}

En la primera conferència vaig considerar una de les maneres en què tractem de concebre'ns a nosaltres mateixos, i també la nostra concepció del món, en relació amb el món independent del qual és una concepció. Fonamentalment, aquest enfocament se centra en com ens afecta el món a l'hora d'arribar a la concepció del món que finalment tenim. Això situa les percepcions, les experiències, els sentiments i altres reaccions al bell mig de l'argument, ja que semblen implicar-les les vies a través de les quals accedim al món tal com l'acabem concebent. Sembla natural que tractem aquestes experiències, sentiments i reaccions com a base o origen per a comprendre la nostra concepció del món.

Tot plegat, expressa la idea segons la qual, si volem comprendre la nostra concepció d'una cosa, la clau és entendre com adquirim aquesta concepció. La 
nostra visió del món s'ha d'entendre que es conforma a partir de tot allò que rebem de la nostra experiència quan interactuem amb el món. Això podria descriure's com un intent d'entendre'ns a nosaltres mateixos i la nostra concepció del món "de baix cap amunt". Entenem allò que ara posseïm, gràcies a la comprensió del seu origen i la manera com ho hem assolit.

En la filosofia, comptem amb una llarga i vigorosa tradició que intenta comprendre el pensament, les creences i les reaccions humanes com a coses de la mateixa mena. En aquesta segona conferència m'agradaria partir d'un altre lloc i resseguir un camí diferent a l'hora de reflexionar, en termes igualment generals, al voltant de nosaltres i del món. Com vaig dir de bon començament, crec que plantejar un problema filosòfic des d'una posició determinada, o tractar-lo d'una manera i no d'una altra, pot marcar una diferència en la nostra comprensió del problema, potser fins i tot en la que creiem que ha de ser-ne la solució. Ara m’agradaria centrar-me no tant en com arribem a la nostra concepció del món, sinó simplement en què és — quina mena de cosa és- en realitat aquesta concepció. Sens dubte, aquesta és la qüestió de què cal tractar en primer lloc; per tal d'explicar com s'ha assolit una cosa, s'ha de tenir una idea bastant clara d'allò que realment es posseeix.

Quina és la nostra concepció de com és el món, independentment de nosaltres i de totes les nostres reaccions envers el món? Què implica la nostra manera de concebre el món independent, i que fa possible que pensem en aquests termes? Les considere preguntes molt generals, per bé que són qüestions factiques que fan referència a nosaltres i a la nostra manera de pensar el món. Han de contestar-se mitjançant la reflexió acurada sobre el que realment pensem i el que hem de ser capaços de fer per poder pensar-ho. Pot semblar que tot això ja té una explicació satisfactòria, però crec que cal parar-li molta més atenció de la que aparentment li parem.

Comencem, doncs, amb la pregunta: Què implica la manera com pensem i què creiem respecte d'un món completament independent de nosaltres i sobre la nostra resposta a aquest món de la manera com sabem que ho fem? Tot això podria descriure's com un intent de comprendre la nostra concepció del món, diguem-ne, "de dalt cap avall", no "de baix cap amunt".

La tradició que defensa una concepció de nosaltres mateixos des d'aquesta perspectiva deriva, en gran mesura, de l'obra de Kant i dels seus prosèlits. Kant va ressaltar les complexes interrelacions entre les diferents maneres de pensar i experimentar allò que, no obstant això, nosaltres considerem un únic món. Va remarcar que la capacitat per a tenir pensaments i experiències de determinats tipus requereix la capacitat per a tenir pensaments i experiències d'altres tipus. Hi ha connexions necessàries, o aparentment necessàries, entre els diferents tipus de pensaments i experiències. Ser capaç de pensar i experi- 
mentar una cosa, i així tenir pensaments i creences sobre un món que és independent de nosaltres, requereix el domini d'una enrevessada xarxa de capacitats interconnectades i de maneres de respondre al món.

Tractar de comprendre millor aquesta xarxa, de veure com funciona, suposa preguntar-nos per les condicions que, per a nosaltres, s'han d'acomplir perquè puguem fer una cosa que tots fem sense cap dificultat o esforç aparents. Creiem que hi ha un món que és independent de nosaltres i que la majoria de les coses que estan en aquest món no depenen, de cap manera, de nosaltres ni de les nostres reaccions. Si volem tenir pensaments o creences sobre un món com aquest és evident que cal que siguem capaços de pensar i creure certes coses. Hem de poder pensar que les coses són d'una determinada manera i no d'una altra. I per a això cal que tinguem al nostre abast certs conceptes o maneres de pensar que fem servir a l'hora de pensar les coses que ens envolten com a coses que són d'una manera determinada i no d'una altra.

Kant va subratllar que, per a tenir conceptes, per a poder pensar que les coses són d'una manera i no d'una altra, cal que posseïm la facultat del "judici": tenir pensaments o creences que són veritables o falses respecte del món a què fan referència. Un judici diu que les coses són d'una manera determinada: hi ha un arbre al jardí, les pomes creixen als arbres, a l'Àfrica hi ha muntanyes, l'herba és verda, plou a Londres, etc. Un judici que és vertader o fals representa el món d'una manera determinada i no d'una altra. Acceptar o subscriure un judici com aquest és acceptar o creure que les coses són com aquest judici diu que són. Tot allò que acceptem, o que podríem subscriure, és allò que constitueix la nostra concepció del món. En aquest punt començàrem.

Vam veure que adquirim creences com aquestes per mitjà de la interacció amb el món en què arribem a creure; el món ens afecta a través dels òrgans sensorials. Però poder comprendre allò que ens succeeix en la nostra experiència sensorial o perceptiva no s'explica, simplement, pel fet que el món ens afecte de certes maneres. Fins i tot el fet de respondre sempre de la mateixa manera als mateixos tipus d'impactes sensorials no ens proveeix, per si mateix, de determinades maneres de pensar allò que succeeix. Per tal que aquests impactes sensorials contribuesquen, com efectivament fan, a la nostra manera de pensar o creure certes coses sobre com és el món, hem de ser capaços de fer alguna cosa amb aquestes experiències sensorials. Allò que experimentem ha de tenir un significat per a nosaltres; cal que puguem pensar i comprendre, de determinades maneres específiques, el que ens presenta la nostra experiència sensorial.

Cadascú de nosaltres pot fer això perquè tots participem d'una pràctica lingüística que fem servir tothora i que ens dóna els recursos necessaris per a pensar en nosaltres mateixos i en com creiem que és el món. Compartim amb la nostra comunitat lingüística la capacitat de parlar i de pensar sobre arbres, 
pomes, muntanyes, herba, pluja i altres coses d'aquest tipus, de manera que tots ens entenem. I la majoria de coses que creiem que són de tal manera, entenem que són així amb independència que algú les perceba realment o no, o crega que són així o no. Quan se m'acut pensar, per exemple, que hi ha muntanyes a l'Àfrica, per descomptat, hi ha algú que està realment pensant-ho. Estic pensant en això, però allò que pense — que hi ha muntanyes a l'Àfricaés així, o no ho és, tant si algú ho creu realment com si no. Això és el que vull dir amb l'expressió "pensament objectiu": pensaments o creences que s'entenen com a veritables o falsos, independentment de si algú hi pensa, creu o reacciona de qualsevol altra manera.

Els conceptes que utilitzem quan creiem coses com aquestes i, per tant, quan construïm una concepció d'un món objectiu, són els mateixos conceptes que també fem servir amb la finalitat de trobar un sentit a les percepcions, les experiències i els sentiments que tenim en resposta al món que ens envolta. Si m’agrada pensar que les pomes creixen als arbres, per exemple, estic tenint una experiència que no podria tenir si no creguera que les pomes, de fet, creixen als arbres. Si considere que a vostès també els agrada pensar que les pomes creixen als arbres, pense que vostès també creuen que les coses són d'aquesta manera. Són experiències que ni vostès ni jo no entendríem que tenim si no creguérem que el món objectiu que ens envolta és d'una manera determinada. Fins i tot per a tenir una sensació com aquesta hem de posseir els conceptes i les capacitats del judici objectiu, que són conceptes i capacitats que es requereixen per a poder pensar que el món és d'una manera i no d'una altra. Això és veritat tant per a l'experiència de contemplar i gaudir la bellesa del verd fosc d'un camp que tenim al davant com per al sentiment i el desig d'evitar la incomoditat de la pluja freda a Londres.

Tots som capaços de tenir aquestes experiències. I sabem que hi som capaços perquè tots compartim els conceptes necessaris per a poder pensar sobre nosaltres mateixos i sobre el que existeix al món de la manera com ho fem. Per tal d'entendre'ns a nosaltres mateixos com a individus capaços de tenir experiències i sentiments com aquests hem d'acceptar que el nostre món és d'una manera i no d'una altra. I la majoria de les maneres en què entenem el món en tenir aquestes experiències són maneres en què pensem que el món és, encara que ningú el perceba o el pense d'aquesta manera. La idea kantiana que afirma que podem donar sentit a les coses només si apliquem conceptes en els judicis sobre com són les coses amb independència de nosaltres es fa extensiva a la nostra manera de donar sentit al que trobem en les nostres experiències. En paraules de Kant, aquestes experiències serien "com no res per a nosaltres" si no pensàrem sobre el món objectiu de certes maneres. Com que els conceptes que apliquem per donar sentit a les nostres experiències són els mateixos que 
apliquem en la reflexió relativa a un món independent de nosaltres i de les nostres experiències, sembla que el pensament i l'experiència van de la mà. Com va igualment de la mà la comprensió de la nostra experiència i la comprensió del món.

En la primera conferència, vam considerar l'estatus que tenen al món coses com ara la bellesa, els colors, els sabors i les olors, la causalitat i els valors de les coses. Des d'una comprensió "subjectivista" d'aquestes coses en què sembla que creiem, s'hi deia que les nostres experiències, sentiments $i$ altres reaccions jugaven un paper important en les nostres creences. Són experiències i sentiments que no es consideraven experiències de coses presents realment al món, a què aquestes creences fan referència. Troben la seua naturalesa o el seu origen només en nosaltres $\mathrm{i}$, per tant, revelen només alguna cosa sobre nosaltres, els subjectes perceptors a qui pertanyen les experiències; no res en absolut sobre com és el món independentment de nosaltres. Es va considerar que allò que obtenim en l'experiència sensorial era separable, i per tant comprensible independentment, d'allò que creiem que és al món independentment de nosaltres $\mathrm{i}$ de com hi reaccionem. Però vaig defensar que la concepció de l'experiència o el sentiment que és necessària per a fer convincents, $\mathrm{o}$ fins $\mathrm{i}$ tot raonables, aquests plantejaments "subjectivistes" és una concepció molt restringida i austera del tipus d'experiències que som capaços de tenir.

Aquesta concepció austera o restringida de l'experiència sensorial o perceptiva té una llarga i distingida història en filosofia. Ha estat present des de l'antiguitat, no només en Demòcrit, com ja hem vist, sinó també, d'una manera més notable, en Plató. Aquesta mateixa concepció la va defensar explícitament Descartes en el provocador desafiament que va plantejar als sentits com a font de coneixement del món. Va plantejar la qüestió completament general de si podem conèixer mai res sobre el món que ens envolta únicament per mitjà de la percepció: mirant, sentint, tocant, assaborint i olorant les coses. Descartes va defensar que, com a molt, exclusivament per mitjà de la percepció només podem conèixer allò relatiu a les experiències perceptives que tenim en el moment, no res més.

Descartes va il.lustrar la qüestió servint-se de les experiències que tenim quan somiem. Va pensar que allò que obtenim a partir de l'experiència perceptiva quan estem completament desperts, amb els ulls i les orelles ben oberts, i fins i tot en circumstàncies òptimes, no és millor com a font de coneixement del món que allò que copsem en les nostres experiències oníriques. Quan somiem, veiem, escoltem i sentim les coses d'una determinada manera, però Descartes creia que les coses ens semblen de la mateixa manera fins i tot quan allò que experimentem ocorre realment al nostre voltant. A partir de la nostra experiència perceptiva no podem distingir el somni de la vigília. Aquest 
és el punt decisiu del desafiament de Descartes a la possibilitat de conèixer el món. L'experiència sensorial, per si mateixa, ens planteja un dubte idèntic quan estem desperts, i no somiem, que quan estem adormits i somiant que les coses són d'aquesta o d'aquella manera al món.

Descartes no pretenia afirmar que la vida és un somni o que sempre somiem, ni tan sols que no podem saber mai si estem somiant o no. Només volia dir que allò que realment copsem a través dels sentits, la nostra experiència quan estem desperts, no és res més que el que copsem quan estem somiant. En tots dos casos, l'única consciència d'aquestes experiències que podem tenir és la de la seua aparença, i això és tot. Fins i tot si allò que s'esdevé al nostre voltant resulta ser exactament igual a allò que les nostres experiències ens fan creure que és, i malgrat que ens sentim segurs que és així, de ben segur que podriem tenir experiències com aquestes encara que aquestes coses no ocorregueren. Així doncs, exclusivament per mitjà de la percepció sensorial no podem conèixer mai allò que succeeix al món que ens envolta.

Descartes presenta aquest desafiament als sentits com una qüestió epistemològica. Ací no consideraré aquest qüestionament general del coneixement. Més important per als nostres propòsits és la concepció de l'experiència perceptiva que hi ha al darrere. Si Descartes té raó, la percepció sensorial mai no ens posa directament en contacte amb les coses tal com són al món en què creiem viure. Per a arribar a concebre l'experiència d'aquesta manera no cal que invoquem, en particular, la possibilitat de somiar, ni tan sols que posem en dubte tot allò que creiem saber. Seria suficient amb trobar qualssevol altres consideracions que també semblen donar suport a la idea que l'experiència perceptiva no arriba a atènyer res existent al món que creiem percebre.

$\mathrm{Al}$ segle XVII, John Locke va reprendre i desenvolupar aquesta concepció austera de l'experiència perceptiva en l'anomenada "nova faiçó de les idees". Com la de Descartes, aquesta va ser també una teoria general de la percepció sensorial, però, per alguna raó sorprenent, la idea que afirma que en realitat no percebem mai res existent al món independent no es va considerar una amenaça per al coneixement. O, si més no, la majoria dels defensors d'aquesta concepció de la percepció sensorial no semblaven estar-ne gens preocupats. En el nou context, aquesta teoria de la percepció va ser considerada principalment com una contribució a la teoria del coneixement: tracta d'explicar com allò que Locke anomena "els materials del nostre pensament" aconsegueixen entrar en la ment primerament i què fan els individus amb aquests "materials" una vegada estan en la ment. Segons aquesta teoria, l'experiència perceptiva ens proporciona una cosa anomenada "idees", amb diverses qualitats sensorials, que es presenten a la ment en les nostres vivències. Atès que l'abast d'allò que podem pensar és, òbviament, molt superior a allò que en realitat hem percebut, hem 
de ser capaços de fer ús de les "idees" que concebem amb la finalitat de construir pensaments i creences sobre coses que no hem experimentat mai abans. Segons Locke, som capaços de fer-ho, i això explica l'abast gairebé il.limitat de la possibilitat de pensar, perquè fins i tot els pensaments més "complexos" que podem tenir es basteixen amb la combinació, de diferents maneres, de les "idees" simples que ens vénen directament de l'experiència sensorial.

Aquesta concepció de l'experiència i del pensament ha resultat ser extraordinàriament influent. La majoria dels filòsofs britànics del segle XviII la van acceptar sense discussió, igual que molts dels seus hereus filosòfics durant gran part del segle xx. El que ara mateix em sembla més interessant d'aquesta teoria, si fóra certa, no és saber si és possible conèixer res sobre el món per mitjà únicament de la percepció sensorial. Crec que, pel que fa a aquesta qüestió, Descartes tenia raó. Si tot allò que obtenim mitjançant la percepció sensorial fóra un conjunt de dades limitades, que Descartes considerava que era tot el que la percepció ens pot facilitar, crec que ningú no podria mai saber res sobre el món més enllà d'aquestes dades. Tot i això, molts filòsofs al segle xx es van resistir a acceptar aquesta implicació i van maldar per mostrar que el coneixement del món es pot explicar, ni tan sols, sobre una base tan austera. Igualment, sembla que avui dia alguns filòsofs tracten de seguir aquest camí.

Però crec que, ara per ara, més interesant que aquest problema epistemològic és preguntar-nos si seria possible concebre l'existència d'un món independent de nosaltres, tot i que els límits de la nostra experiència perceptiva estiguen tan restringits com aquesta teoria ens diu que estan. Amb aquesta experiència sensorial limitada, ¿tindríem ni tan sols els recursos imprescindibles per a poder concebre un món independent i arribar a comprendre els tipus de pensaments necessaris per a poder donar-li sentit com a quelcom independent de nosaltres? La meua sospita és que la resposta a aquesta qüestió tan genèrica és probablement negativa. I crec que són igualment qüestionables les creences que hem estat considerant sobre la bellesa, els colors i els sabors, la causalitat i el valor de les coses, tal com s'entenen des dels punts de vista "subjectivistes" que hem examinat.

Per a aquests plantejaments "subjectivistes", les experiències perceptives, els sentiments i les reaccions, d'alguna manera, són part o estan implicades per les coses mateixes que creiem quan pensem que les coses són belles, tenen color, són saboroses, estan causades, són bones o dolentes. Però aquestes experiències no s'entenen com a percepcions de quelcom tal com és al món amb independència de nosaltres. La qüestió que deixàrem pendent es preguntava per com eren realment aquestes experiències, tal com el "subjectivisme" les concep, i exactament quin paper juguen en les creences que tenim en cada cas. Així doncs, per al "subjectivisme", la pregunta és si podríem tenir, o fins i tot 
concebre que nosaltres mateixos tenim, les creences que el "subjectivista" pensa que tenim sobre la bellesa, el color, la causalitat i els valors de les coses. ¿Podríem arribar a tenir aquestes creences si les experiències sensorials i els sentiments que el "subjectivisme" afirma que estan implicats en el fets de tenir-les foren tan austers o restringits com aquesta concepció defensa?

Per exemple, quan ens sentim impressionats per la bellesa d'una cosa que contemplem — una pintura, una escultura o una persona-, sembla que allò que ens mou és la bellesa que trobem en la cosa. Que reaccionem d'aquesta manera implica que tenim determinada experiència sensorial, però aquest és un tipus d'experiència que no podríem tenir si la cosa que tenim davant nostre no ens semblara bella. Atribuir la bellesa a la cosa, tal com fem, sembla imprescindible per tal que siga possible tenir exactament aquest tipus d'experiència. És molt més que tan sols una experiència agradable, o fins i tot molt agradable. Si tenim una experiència agradable d'una cosa, o si en gaudim de certa manera, no és necessari que la cosa ens semble bella. Aquest és només un tipus d'experiència diferent. Així, el mer fet que els sentiments estiguen involucrats en els nostres judicis relatius a la bellesa, com manté el "subjectivisme", no implica que puguem concebre els sentiments involucrats en aquests judicis de la manera restringida que exigeix el "subjectivisme".

El "subjectivista" ha de donar compte de què és exactament allò que atribuïm a un objecte quan diem o creiem que és bell. No sols el considerem agradable o plaent, ni tan sols excitant; això no és el mateix que considerar-lo bell. La qüestió rau en el fet que sembla difícil trobar altres paraules o idees per a descriure o definir què és la bellesa o què pensem quan considerem que una cosa és bella. Cal que el "subjectivisme" tinga una resposta per a aquesta pregunta, però aquesta posició afirma que no podem aprehendre mai la idea de bellesa per mitjà de trobar-la exemplificada en els objectes que percebem al món; la nostra experiència sensorial no conté cap propietat com aquesta. Així, sembla que els nostres pensaments i creences tocants a la bellesa s'han de construir, d'alguna manera, a partir de quelcom que efectivament trobem en la nostra experiència perceptiva. Però, tal com la concep el "subjectivisme”, ¿̇comprèn l'experiència perceptiva qualitats en brut que, conjuminades, puguen produir res d'equivalent a la idea de bellesa? Sembla que, per a la concepció "subjectivista" restringida de l'experiència, la resposta ha de ser que no. Però respondre als objectes que ens envolten, com efectivament fem, creient que alguns són bells requereix la possessió d'alguna idea o concepció d'allò que anomenem bellesa.

El "subjectivista" defensa que no hi ha cap propietat anomenada "bellesa” que siga pròpia dels objectes que considerem bells. Pel que fa a aquests objectes, la màxima certesa que tenim al nostre abast és que hi responem de 
certa manera: els considerem bells. Així, d'acord amb el "subjectivisme", hi ha quelcom en aquests objectes i quelcom en nosaltres que, en tant que en som perceptors, ens mena a creure que els objectes són bonics. Però, què arribem a creure sobre aquests objectes, segons el "subjectivista"? Aquesta creença resta, a hores d'ara, per explicar. El problema és saber a què equival aquesta creença. Què creiem quan creiem que un objecte és bell? Amb una concepció restringida d'allò que ens és accessible per mitjà de l'experiència sensorial, ¿pot el "subjectivista" explicar quina cosa és aquesta creença, o com podríem mai aprehendre la idea de bellesa necessària per a poder jutjar que una cosa és bella? Qualsevol intent d'explicació de la creença sembla fer servir la mateixa idea de bellesa que pretén explicar.

Cal reconèixer que la idea de bellesa és molt colpidora. Tot i que aparentment l'apliquem amb tota confiança a alguns dels objectes que percebem, sembla que no hi ha termes equivalents amb què explicar-la o definir-la. Pot ser que, simplement, hàgem d'acceptar aquest fet. No totes les idees poden expressar-se en termes distints i, alhora, equivalents, ni totes es poden bastir a partir d'ingredients més simples. Com hem vist, la dificultat per a la comprensió "subjectivista" dels judicis de bellesa rau en el fet que mai no trobem exemples de bellesa en la nostra experiència perceptiva, però cal que posseïm alguna idea de bellesa que apliquem a les coses que creiem que són belles.

Sembla que aquesta dificultat no apareix si tenim en compte les nostres creences sobre els colors de les coses. En aquest cas, a diferència del cas de la bellesa, sembla indubtable que, en efecte, trobem exemples de colors en la nostra experiència perceptiva. Això suggereix que, per a afaiçonar les idees dels colors de les coses, que fem servir per atènyer la creença que els objectes són de color, podem emprar aquestes experiències dels colors. Així doncs, el "subjectivisme" podria explicar de quina manera els colors dels objectes del món independent "es troben només a l'ull de l'observador", per molt que els colors es manifesten en les mateixes experiències dels subjectes perceptors.

Hem vist que, segons el "subjectivisme", els colors verd, roig, blau i tots els altres apareixen en la meua experiència perceptiva com a sensacions o impressions simples. Les experiències, per si mateixes, només ens aporten les qualitats que es presenten en aquestes experiències. Aquesta és la concepció austera, restringida, del que ens proporciona l'experiència perceptiva per si mateixa. El "subjectivisme" manté que el que crec quan crec que l'herba és verda, o que les pomes són roges, és que l'objecte és de tal manera que produeix sensacions de verd, o de roig, a certs tipus d'observadors en determinades circumstàncies. Això explicaria com puc creure, de la manera que siga, que l'herba és verda, encara que el verd no estiga realment present en l'herba. Des d'aquest punt de vista, el color verd està present en la meua experiència; en l'herba només està 
present la tendència o el poder de produir, a determinats observadors, sensacions de certs tipus distintius. Quan dic i crec que l'herba és verda, crec una cosa diferent del que crec quan crec que estic tenint una sensació de verdor. Vam veure que la qüestió es complica si ens ocupem de la bellesa, atès que segons el "subjectivisme" no tenim mai sensacions de bellesa en la nostra experiència sensorial. Així doncs, és difícil entendre com podríem posseir una idea de la bellesa. Però sembla que aquesta dificultat no es presenta amb el verd, el roig o el blau, perquè podem extraure les idees necessàries per a bastir les nostres creences sobre els objectes de color directament dels colors que percebem mitjançant les nostres sensacions.

He assenyalat que la dificultat a què s'enfronta el "subjectivisme" pel que fa a la idea de bellesa sembla aparèixer també en les concepcions "subjectivistes" de les nostres creences sobre les connexions causals. Hume pensava que, una vegada trobem que un tipus de cosa sempre ocorre tot seguit a coses d'un altre tipus, ens formem la creença que hi ha una relació causal entre aquests dos tipus de coses. Creiem que una cosa del segon tipus ha d'ocórrer si es produeix una cosa del primer tipus. Però, des del punt de vista de Hume, aquesta idea -la necessitat o haver de - és una cosa que no percebem mai directament en la nostra experiència. Pensava que no existeix enlloc una connexió tal entre les coses, ni tan sols en les coses que s'esdevenen en la nostra ment o en la nostra experiència immediata. El que trobem a l'experiència és sempre una successió d'un tipus d'esdeveniment rere altre, potser una i altra vegada. Tot i que no hi ha una relació de necessitat en cap d'aquestes seqüències, n'extraiem la idea de necessitat o de connexió causal, i així arribem a creure que les coses estan connectades causalment. Aquesta idea de necessitat no és definible segons altres termes que siguen diferents i equivalents, alhora. Llavors, ateses les limitacions estrictes de la nostra experiència perceptiva, ¿com podríem formar-nos o donar sentit a una idea com aquesta? En realitat, crec que Hume no va superar mai aquest obstacle. És el mateix tipus de dificultat que es planteja en qualsevol tractament "subjectivista" de la bellesa.

Allò que podria semblar que funciona, si no per a la bellesa, almenys per a les creences sobre els colors de les coses, no pareix prometedor en el cas de la necessitat. Pel que fa als colors, potser un "subjectivista" podria emprar les sensacions de color que trobem en la nostra experiència per explicar el que creiem quan creiem que els objectes són de color. Però, des del punt de vista "subjectivista", no tenim mai sensacions o impressions de necessitat. Per mitjà de l'experiència perceptiva només percebem seqüències en què esdeveniments d'un tipus ocorren després d'esdeveniments d'un altre tipus. En aquest cas, hi ha una dificultat específica que deriva del fet que, encara que tinguérem sensacions o impressions relatives a la necessitat, no guanyaríem gaire. Un "subjecti- 
vista" respecte de la causalitat no podria mantenir —en paral-lel amb l'explicació normal dels color dels objectes_ - que allò que creiem quan creiem que dos esdeveniments estan causalment connectats és que percebre seqüències regulars d'esdeveniments semblants ens fa creure que els esdeveniments d'aquests tipus estan causalment connectats. Això no podria formar part de manera coherent d'una concepció "subjectivista" de les nostres creences sobre la causalitat que aspire a ser consistent perquè, segons aquesta mateixa concepció, algunes coses al món tenen el poder de produir pensaments i creences de determinada classe en els perceptors. La qual cosa implica, al capdavall, que les connexions causals realment s'escauen al món independent. I això és, precisament, el que una posició veritablement "subjectivista" ha de refutar o desllorigar. Si mantinguera, amb més cautela, no que certs esdeveniments al món tenen realment el poder de produir aquest tipus de creences, sinó només que creiem que algunes coses al món tenen aquests poders, llavors continuaríem sense poder explicar allò que creiem quan creiem en la causalitat. I, si no se'ns presenten mai exemples relatius a la necessitat en cap experiència perceptiva, no podrem explicar com arribem a creure-hi. Igual com en els altres casos que hem considerat, crec que aquesta és també una conseqüència desafortunada de la concepció austera i restringida de l'experiència sensorial amb què es compromet el "subjectivisme". No sembla deixar lloc a una comprensió satisfactòria de nosaltres mateixos com a posseïdors de les creences que sabem que tenim sobre la bellesa i sobre les connexions causals entre les coses d'un món independent.

Crec que aquesta mateixa dificultat s'estén a les temptatives "subjectivistes" que tracten d'entendre les nostres creences o actituds avaluatives envers la bondat i la maldat, o la justícia i la injustícia, de les accions o de les situacions. El problema quedava plantejat, però no resolt, en l'observació de Bertrand Russell que vaig citar. Russell afirmava que volia acceptar el "subjectivisme" relatiu als valors, però que no es veia capaç de creure que allò que hi ha de dolent en la crueltat sense sentit és només que a ell no li agradava. Dir que el que té de dolent la crueltat sense sentit no és sols que a Bertrand Russell no li agrada, sinó que no agrada a ningú, tampoc no resol la qüestió. Tenir aversió a una cosa és distint de pensar que és injusta, dolenta o maliciosa. Aquest és el pensament o la reacció que cal tenir en compte. L’observació de Russell mostra que ha d'haver un ingredient pròpiament avaluatiu quan pensem que una cosa és injusta o dolenta. Aquest aspecte avaluatiu roman encara que la idea que una cosa és dolenta estiga implicada en l'experiència o el sentiment que tenim envers la cosa. Però, ¿d'on ve aquesta idea distintiva d'injustícia o maldat, si mai no ens topem amb una qualitat com aquesta en res que trobem en la nostra experiència perceptiva?

Hume afirmava que mai no podem trobar el "vici" o el "caràcter viciós" 
que atribuïm a un acte d'homicidi intencionat fins què mirem dins de nosaltres i trobem un "sentiment (o sensació) de desaprovació" envers aquesta acció. Aquest "sentiment" és una sensació, afirma Hume, no un pensament o creença que puguem assolir per mitjà del raonament. Però això planteja el problema de què hi ha al darrere del desgrat que ens provoca la concepció restringida tradicional de l'experiència. ¿Ens seria possible experimentar un sentiment $o$ una sensació de desaprovació envers una cosa sense desaprovar-la realment? ¿O, si més no, sense considerar-la digna de desaprovació? Això suposaria tenir una actitud avaluativa envers aquesta cosa; això és, avaluar l'acte d'una manera negativa determinada. Però si cal una actitud o un judici com aquest que, per tant, forme part de la mateixa sensació o sentiment de desaprovació, no seria en realitat possible tenir una sensació o sentiment com aquest sense pensar que la cosa és digna de desaprovació.

La concepció excessivament restringida de l'experiència no sembla reconèixer que el tipus d'experiència o sentiment que tenim en un moment determinat depèn, sovint, dels tipus de pensaments o creences que hem de tenir per poder viure aquesta mateixa experiència. Per exemple, no podem tenir un sentiment d'orgull, o sentir-nos orgullosos d'una cosa, llevat que pensem que aquesta cosa està vinculada amb nosaltres d'alguna manera. Ens podem sentir orgullosos dels nostres èxits, de la nostra resiliència, dels nostres fills i les seues gestes, però, d'una manera o altra, cal pensar totes aquestes coses en relació amb nosaltres o els nostres esforços. Si no es fa així, no s'hi pot tenir un sentiment d'orgull. Qualsevol cosa que poguérem sentir no seria orgull. Podem dir el mateix sobre la vergonya i molts altres sentiments i emocions. Cal pensar o creure determinades coses per a tenir-ne els sentiments.

El "subjectivisme" tracta d'explicar els pensaments i les creences de caire valoratiu que fan referència a la bondat o la maldat de les accions amb la participació de sensacions o sentiments que no requereixen cap mena de creença en la veritat de res que hi haja al món. Però, si com he plantejat, tenir les sensacions o els sentiments en qüestió requereix la participació de determinades creences avaluatives, no es pot avançar en la defensa del "subjectivisme" si el caràcter distintiu de les creences s'explica apel-lant a sentiments o sensacions. I, per altra banda, si les sensacions i els sentiments en qüestió no impliquen cap actitud valorativa, no poden donar compte d'allò que creiem o sentim quan considerem que una determinada acció és equivocada o dolenta.

Algunes variants del "subjectivisme" consideren els judicis morals o avaluatius no com a declaracions o creences, sinó només com a expressions d'actituds o sentiments. No diem que desaprovem una cosa, o que hi mantenim determinades actituds avaluatives d'altra mena; simplement expressem o mostrem aquestes actituds. Però, una vegada més, cal que ens preguntem què 
són aquests sentiments o actituds que expressem. Si simplement no m’agrada un determinat tipus d'acció i manifeste el meu desgrat sense dir realment que no m’agrada, no mostre així desaprovació envers aquesta acció. Simplement, manifeste el meu desgrat. ¿Podria una cosa que faig o dic ser una expressió de desaprovació, si jo no pensara o creguera en realitat que l'acció en qüestió ha de ser desaprovada o és digna de desaprovació? Però, si mantenir algunes d'aquestes actituds avaluatives és part de la pròpia experiència o sentiment que manifeste envers l'objecte, el fet que els judicis avaluatius siguen expressions, i no declaracions de creences, no ajuda a explicar com podem tenir les idees que necessitem per a mantenir o expressar aquestes actituds avaluatives. Crec que fins ara la filosofia no ha trobat cap punt de vista purament "subjectivista" que ens done una explicació raonable del que creiem quan creiem que l'assassinat està malament $\mathrm{o}$ és inacceptable.

Per fer front a aquest tipus de dificultat, alguns filòsofs han mamprès una línia de pensament que és en certa mesura heroica. No és exactament un tipus de "subjectivisme", però se suposa que té gairebé les mateixes implicacions respecte del món independent. Aquest punt de vista afirma que no hi ha res semblant a la bellesa, o com els colors, els sabors i les olors de les coses, o com la bondat o la maldat de les accions o les situacions, al món independent. Creiem coses com aquestes, però, des d'aquest punt de vista, allò que creiem cas per cas és, parlant estrictament, fals. Al món no hi ha propietats com aquestes. Simplement estem equivocats, errats, quan creiem que n'hi ha.

No crec que això supose una millora respecte al "subjectivisme" com a contribució a la nostra autocomprensió. Com li ocorre al "subjectivisme", això no supera la dificultat que tenim a l'hora d'explicar les nostres creences en termes de quelcom que hem de trobar en la nostra experiència sensorial immediata. El "subjectivisme" tracta d'explicar les creences, enteses de manera correcta, com a majoritàriament vertaderes, fins i tot quan en sentit estricte no es refereixen a allò que podria semblar que es refereixen quan les considerem de manera irreflexiva. Aquesta línia de pensament que he anomenat "heroica" no accepta una simplificació conciliadora d'aquesta mena. Manté que allò que creiem sobre la bellesa, o sobre els colors, els sabors i les olors, o sobre els valors, de les coses és més o menys tal com sembla ser i que no pot expressar-se només en termes estrictament "subjectivistes".

Crec que aquest punt de vista és sensible a les mateixes dificultats que assetgen el "subjectivisme", però es diferencia d'aquest en el que podríem anomenar els fonaments semàntics del significat d'aquestes creences problemàtiques. Accepta la idea que la nostra manera de pensar el món —un món que conté coses belles, de color o valuoses- és més rica que el conjunt del que podem trobar en la nostra experiència perceptiva immediata. Però aquest punt de vista 
"heroic" va més lluny, ja que també manté que la nostra concepció del món ultrapassa no sols allò que podem trobar en la nostra experiència, sinó fins $\mathrm{i}$ tot allò que realment hi ha al món que concebem. Afirma que malencertem en creure en coses belles, de colors, bones, males o perverses, tot i que per diverses raons no puguem deixar de creure en coses com aquestes.

Trobe correcte aquest punt de vista pel que fa a l'aspecte semàntic. Crec que fa bé a oposar-se a la reducció "subjectivista" dels significats o continguts de les creences que mantenim sobre la bellesa, els colors i els valors de les coses del món. Però aquest punt de vista ens ofereix una comprensió evidentment poc satisfactòria de nosaltres mateixos i de les nostres creences sobre el món. Reconèixer que les nostres creences sobre totes aquestes coses són simplement falses, que sempre estem equivocats o sotmesos a l'influx d'una il.lusió quan hi creiem, és un veredicte molt difícil d'acceptar. Com a mínim, caldria tractar d'explicar, en primer lloc, com podríem creure en aquestes coses atès que no atenyen a descriure res que siga així en el món en què hem arribat a creure-les. I, tocant a aquesta qüestió, crec que aquest punt de vista "heroic" no arriba molt més lluny que el "subjectivisme". Seguim sense tenir una comprensió satisfactòria de nosaltres mateixos i del món. Per a poder trobar el tipus d'aclariment que busquem, necessitem un camí nou, diferent i més prometedor.

\section{Conferència III \\ L'EXPECTATIVA D'ASSOLIR L'OBJECTIVITAT}

En la primera conferència, vaig presentar l'ambiciós projecte de tractar d'entendre la relació entre nosaltres i les nostres concepcions del món d'una banda, i el món tal com realment és independentment de nosaltres i les nostres reaccions a aquest, de l'altra. Una estratègia que semblava prometedora considerava que les creences aparentment problemàtiques que hem estat considerant — envers la bellesa, els colors, sabors i olors, els poders causals i els valors o les virtuts de les coses - depenen d'una manera o altra del que és veritat respecte de nosaltres, no del món independent sobre el que pensem. La idea era concebre que totes aquestes propietats en què creiem resideixen, d'alguna manera, només "a l'ull de l'observador". Aquesta estratègia ha semblat molt atractiva a molts filòsofs. En la primera conferència, vaig assenyalar que promet una cosa que crec que busquem. Si fóra possible arribar a comprendre totes aquestes creences a la manera, grosso modo, "subjectivista" que he estat descrivint, plantejaríem, si 
més no, un tipus de comprensió satisfactòriament imparcial i exhaustiva de la nostra condició en el món, que és el que una posició filosòfica d'aquesta mena aspira a trobar.

En la segona conferència no vaig partir d'aquesta estratègia "subjectivista”, sinó d'una descripció molt general de la concepció d'un món independent, que és la que crec que realment tenim. Si aquesta descripció representa amb exactitud la manera com pensem que són les coses al món independent, serà al dedins d'aquesta mateixa concepció del món on qualsevol comprensió "subjectivista" de les creences que hem estat considerant podrà resultar convincent, si és que és possible en alguna mesura. Hi vaig expressar els meus dubtes sobre si, per aquesta via, podíem arribar a una comprensió satisfactòria de nosaltres mateixos. Aquesta estratègia "subjectivista" situa les percepcions, les experiències, els sentiments i altres reaccions psicològiques al bell mig de la descripció d'allò que realment creiem sobre la bellesa, els colors, la causalitat i els valors de les coses del món. I vaig suggerir que la concepció de la percepció, l'experiència i el sentiment que aquesta estratègia accepta es basa en una concepció restringida o austera, que no és gens realista, d'en què consisteix realment la nostra experiència sensorial, perceptiva o sensitiva.

En aquesta conferència, m’agradaria explicar amb més detall com és que aquesta concepció austera de l'experiència representa un obstacle seriós a l'hora d'assolir un tipus de comprensió satisfactòria dels continguts d'aquestes creences. Crec que la concepció "subjectivista" malencerta la interpretació d'allò que realment percebem, sentim i pensem respecte al món independent. Amb una concepció més tolerant i crec que més precisa del que ens pot donar l'experiència, pense que el tipus de "subjectivisme" que hem estat considerant perd el seu atractiu aparent. Crec que podem arribar a entendre com, i per què, allò que ens és accessible a través de l'experiència perceptiva s'ha d'entendre en connexió amb la manera com pensem i creiem que són realment les coses al món independent. Per tant, una i altra cosa han d'anar més o menys de la mà. Si realment existeix aquest tipus de connexió entre els continguts de l'experiència i els continguts del pensament, hi ha bones raons per a pensar que, pel que fa a aquestes creences aparentment problemàtiques, mai no podríem arribar al tipus de comprensió completament "independent" i purament "experiencial" que ens promet el "subjectivisme". Això seria un obstacle seriós — crec que fatal- per a l'èxit del "subjectivisme". I, si això és així, es planteja immediatament la qüestió de si hi ha alguna altra manera amb què podem esperar arribar al tipus de comprensió imparcial i completa de nosaltres mateixos i del món independent, que sembla que és el que busquem. Al final de la conferència, tornaré a aquesta qüestió inquietant $\mathrm{i}$ a algunes de les seues conseqüències. 
Vull començar amb la bellesa; però, com abans, no tinc molt a dir que ens puga resultar útil per a poder aprofundir en la reflexió o per a comprendre millor aquesta desconcertant idea. Tots tenim una concepció de la bellesa i l'ús que fem d'aquesta idea és important per a nosaltres. Però crec que necessitem una comprensió millor d'allò que realment diem, pensem o sentim sobre una cosa determinada quan creiem que aquesta cosa és bonica. El "subjectivisme" afirma que la bellesa és quelcom que "es troba només a l'ull de l'observador"; quan creiem que certes coses són boniques simplement estem responent a aquestes coses d'una determinada manera peculiar. Hi ha part de veritat, en això; no hi ha dubte que, en les circumstàncies adequades, molts objectes del món tenen aquest tipus d'efecte sobre nosaltres. Però aquest argument, en si mateix, no aporta res. Per descomptat que responem de manera distinta a les coses que considerem belles, car les considerem belles. La pregunta és quina cosa és exactament aquesta reacció distintiva i de quina manera ens afecta el món per a fer-nos creure allò que creiem sobre aquestes coses.

Què obtenim per mitjà de l'experiència sensorial dels objectes que considerem bells? Certament, d'alguns d'aquests objectes obtenim sensacions agradables o plaents, però només aquestes sensacions no bastarien per a poder respondre a la pregunta. Fins i tot les experiències emocionants, excitants o impressionants no bastarien per a explicar la nostra creença o experiència de la bellesa en particular. Podem estar contents, emocionats, excitats o fins i tot meravellats per una cosa sense considerar-la bella. Per poder experimentar la bellesa particular d'una cosa sembla necessària una idea prèvia de bellesa —alguna manera de pensar o donar sentit a les coses com a belles o no. Segons la concepció "subjectivista", en la nostra experiència sensorial no som conscients de res que siga la bellesa d'una cosa que veiem o sentim, ni ho podríem ser. Però parlem de la bellesa de les coses, i hi creiem. Quan diem coses que creiem que són vertaderes sobre alguns dels objectes del món que ens envolta, fem ús de la que sembla ser una idea irreductible, no explicable d'una altra manera, de bellesa. Així, roman el misteri que envolta la idea de bellesa i allò que pensem i sentim en experimentar la bellesa d'una cosa. El "subjectivisme", a hores d'ara, no sembla aportar res més.

Si tractem seriosament d'acceptar un punt de vista "subjectivista" relatiu a les nostres creences sobre les connexions causals entre les coses al món, es planteja una dificultat similar. Vam veure que Hume pensava que copsem la idea de causalitat, o de connexió necessària, en l'experiència sensible, tot i que no trobem mai en la nostra experiència cap cas real d'una cosa que en cause una altra. Fins i tot si som conscients de certes seqüències d'esdeveniments que ocorren en les nostres pròpies ments, mai no som conscients de les connexions causals entre esdeveniments. Aleshores, què és allò que realment pensem sobre 
dos esdeveniments quan creiem que estan connectats causalment? I, com copsem la idea de causalitat necessària per a poder tenir aquesta creença? Cal que el "subjectivisme" elabore una resposta creible a aquesta pregunta. No hi ha prou amb dir que creure en les connexions causals entre les coses és una manera particular de reaccionar a allò que trobem en la nostra experiència. Això és cert, però de nou la pregunta és quina cosa és exactament aquesta reacció singular —aquesta idea distintiva de causa - i de quina manera tot allò que obtenim en l'experiència perceptiva ens porta a experimentar-la.

També en aquest cas la idea de la relació causal que entenem i utilitzem no és equivalent, segons Hume, a cap mena de combinació d'experiències o idees que trobem en la nostra experiència sensorial. Però fem servir aquesta idea de connexió causal, aparentment irreductible i de moment inexplicable, a l'hora de pensar les coses que creiem veritables sobre els objectes al món que ens envolta. Afirmar tan sols que aquestes creences són reaccions a la manera com ens afecta el món, altra vegada, no contribueix a explicar allò que creiem. Sembla que no podem assolir una comprensió "subjectivista" satisfactòria d'allò que realment creiem sobre les connexions causals entre les coses, de la mateixa manera que ens vam quedar sense una comprensió satisfactòria de la nostra idea de bellesa. En tots dos casos, les restriccions en l'abast d'allò que creiem que ens és accessible merament per mitjà de l'experiència perceptiva semblen deixar-nos sense recursos per poder explicar el contingut d'aquestes creences, i així no hi ha manera d'explicar com les copsem.

Com vaig esmentar en la segona conferència, el "subjectivisme" s'enfronta a una dificultat afegida quan tracta amb la causalitat en particular. Es tracta del punt de vista que defensa que arribem a creure en la connexió causal de la manera com ho fem tan sols per com ens afecta perceptivament el món, i no per cap connexió causal entre les coses que realment percebem. Però intentar anar massa lluny en la direcció del "subjectivisme" suposaria admetre que, després de tot, hi ha realment connexions causals entre algunes coses del món. Aquest afirma que mai no percebem la causalitat, però que, no obstant això, certa cosa causa que creguem que les coses estan causalment connectades. Així doncs, si acceptem aquesta interpretació de l'origen de les nostres creences no podrem mantenir consistentment per més temps el punt de vista "subjectivista" segons el qual l'existència de totes les connexions causals depèn de les nostres respostes peculiars al món. Hauríem concedit que al món operen algunes connexions causals, amb independència de si pensem que les coses estan causalment connectades o no. Aquesta sembla ser, si fa no fa, la manera com pensem sobre la causalitat del món. Crec que tots sabem, o almenys creiem, que àdhuc si tot això que ara és cert sobre els perceptors i les seues respostes deixara de ser-ho — i tant hi fa que hi haja o no hi haja hagut mai cap 
perceptor-, algunes coses continuarien causant que ocórreguen altres coses al món, com sembla que s'escau. No trobe que la nostra concepció del món siga la d'un món en el qual simplement no hi hauria cap mena de causalitat sense nosaltres i sense com responem normalment al que s'esdevé al nostre voltant.

Crec que tot això mostra, com ja he assenyalat, que aquest "subjectivisme" podria ser satisfactori si fóra capaç d'explicar, de manera convincent, les nostres idees i creences sobre la bellesa, la causalitat o el que siga. A més a més, cal que el "subjectivisme" explique aquestes idees únicament en termes d'experiències, sentiments o reaccions que podríem entendre que tenim, tot i que creguérem que no hi ha res al món que posseesca alguna de les qualitats que trobem en la nostra experiència.

Molts filòsofs creuen que el "subjectivisme" pot fer front a aquest repte, almenys en el cas de les creences sobre els colors de les coses i les creences avaluatives sobre la bondat o la maldat de les accions o de les situacions. Des d'aquesta perspectiva, sembla àmpliament acceptat que el "subjectivisme" avança pel camí correcte. La resta d'aquesta conferència la dedicaré a aquestes dues creences, en concret. Allò que es considerava que era específic, i per això mateix distintiu, d'aquestes creences — exceptuant-ne la bellesa i la causalitat- era que podíem trobar alguna cosa al dedins de la nostra experiència perceptiva que poguérem fer servir per a explicar allò que creiem sobre els colors de les coses, o la seua bondat o maldat, per mostrar que els colors de les coses, i la seua bondat o maldat, depenen fonamentalment del tipus d'experiències, sentiments o respostes que els subjectes perceptors o "observadors" podrien tenir de les coses que observen i amb què interactuen al món.

Se'ns diu que, en el cas dels colors, trobem percepcions sensorials d'aquest o aquell color — veiem verd, veiem roig, veiem blau, etc. No hi ha dubte que tenim experiències perceptives d'aquesta mena, però si es pretén que servesquen a la causa del "subjectivisme" han de concebre's com a sensacions o impressions de les quals només prenem consciència directa d'algun aspecte o caràcter de l'experiència sensorial en si mateixa. Perquè el "subjectivisme" siga coherent, ha de ser cert que, en sentit estricte, no veiem mai el verd de l'herba o el roig d'una poma. Veiem verd o roig, però aquest fet es concep tot just com una qüestió relativa a tipus particulars de sensacions que experimentem. Potser copsem aquesta mena de sensacions davant la presència física de l'herba o de les pomes, però s'han de concebre com a sensacions d'un tipus que podriem copsar tant si les coses al món foren dels colors que veiem com si no, igual com podem tenir una sensació dolorosa sense pressuposar que l'objecte que causa aquesta sensació també té un mal. I, com els dolors, la nostra consciència dels colors, en les "sensacions de color", s'ha de concebre com quelcom que podríem copsar sense creure res sobre els colors dels objectes del món que ens envolta, o ni 
tant sols ser capaços de creure-ho. Les percepcions sensorials de color s'haurien de concebre com a presentacions de les qualitats de l'experiència perceptiva, $\mathrm{i}$ prou.

$\mathrm{Si}$, per mitjà de la nostra experiència immediata, copsem únicament elements purament sensorials com aquests, la tesi "subjectivista" és que allò que creiem quan creiem que l'herba que ens envolta és verda, o que les pomes de l'arbre són roges, és només que l'herba o les pomes són el tipus de cosa que podria causar que observadors com nosaltres copsaren, en determinades circumstàncies, sensacions de verd o de roig. Així doncs, el color d'un objecte dependria del tipus de sensacions visuals que aquest objecte produiria a observadors com nosaltres en determinades circumstàncies. En aquest sentit, el color de l'herba, de les pomes, o de qualsevol altre objecte del món dependria de l'observador - “es troba només a l'ull de l'observador"-, en el sentit que el color de l'objecte es determina exclusivament pel tipus de reaccions que els perceptors tindrien realment davant objectes d'aquest tipus.

Crec que aquesta és una concepció excessivament restringida de l'experiència perceptiva, si volem explicar allò que creiem quan creiem que l'herba és verda o que les pomes són roges, o, en general, que els objectes són de color. Crec que per aquest camí no és possible esclarir el concepte de color de les coses que realment emprem per tal de concebre les nostres creences sobre els colors de les coses. Segons aquest punt de vista "subjectivista", el color d'un objecte no és més que un cert tipus de poder o propensió de l'objecte que produeix determinats efectes a certs tipus de perceptors. Els objectes verds són diferents dels objectes rojos només perquè tenen el poder de produir diferents tipus d'efectes que els objectes rojos. Però, ¿̇com podem identificar o comprendre les diferències entre aquests efectes, els diferents tipus de sensacions en si mateixes? Se'ns diu que quan copsem un o altre dels dos tipus de sensacions som directament conscients de coses diferents. Tanmateix, si això ha de contribuir a explicar la diferència que entenem que hi ha entre les experiències de verd i les experiències de roig, hem de ser capaços de "fer" alguna cosa amb aquesta diferència per poder a entendre-la d'alguna manera. Com va subratllar Kant, allò que experimentem ha de significar alguna cosa per a nosaltres, hem d'entendre-ho d'una manera determinada i no d'una altra, si és que l'experiència ha de poder contribuir a la nostra manera de pensar i de creure allò que creiem sobre el món. I, ¿đde quins termes o maneres de pensar disposaríem per a poder entendre la diferència entre les "sensacions de verd" i les "sensacions de roig" segons les concep el "subjectivisme"?

Podríem introduir mots per a representar cadascun dels diferents tipus d'experiència. Però, amb només les qualitats de les experiències per seguir endavant, ¿què podríem entendre que signifiquen aquests nous mots introduïts? 
¿Servirien per a alguna cosa més que no siga dividir les sensacions en qüestió en dos tipus diferents? Aquesta divisió no diria res sobre quina és realment la diferència entre els dos tipus de sensacions. No s'hi especificaria de què són sensacions aquests tipus distints de sensacions.

Quan percebem el color verd, crec que identifiquem la propietat de la qual som conscients dient que és una propietat que seria correcte atribuir a un objecte, si i només si aquest objecte és verd. Aquesta explicació fa ús de paraules relatives al color tal com entenem que cal aplicar-les als objectes del món públic. Aquestes paraules relatives al color tenen el significat que tenen en aquests usos exclusivament perquè, com a pràctica general, tots convenim a utilitzar-les per dir coses sobre els colors dels objectes que ens envolten. Sense aquests judicis sobre els colors de les coses, que compartim àmpliament, crec que no hi hauria cap mena de termes relatius al color amb significat $i$, per tant, no hi hauria res que ens permetera entendre que els objectes són d'aquest o d'aquell color. Lacord general pel que fa als colors de les coses d'un medi determinat és una condició perquè una comunitat tinga qualsevol terme relatiu al color i, així, perquè tinga creences sobre els colors de les coses. A més, els termes relatius al color que apliquem als objectes que ens envolten són els mateixos termes que utilitzem per descriure les nostres experiències perceptives referides al color. Per tant, en identificar una sensació o percepció com una percepció de verd, ens basem en la nostra comprensió d'allò que pensem quan pensem que un objecte és verd. Això no vol dir que hàgem de pensar que hi ha un objecte verd davant nostre cada vegada que percebem el color verd. Però crec que quan identifiquem el tipus de percepció que estem tenint ens basem en la nostra comprensió d'allò que implica que un objecte siga d'un color determinat. Per a poder identificar les percepcions com a percepcions d'aquest o d'aquell color, es requereix la capacitat de pensar que un objecte siga d'un color determinat.

Tots tenim aquesta capacitat de pensar i creure que els objectes són d'aquest o d'aquell color. La creença que els objectes són de color està implicada en l'exercici d'aquesta capacitat, igual com ho està en la comprensió que tenim de nosaltres mateixos com a perceptors d'aquest o d'aquell color. Però, si això és així, si donem i hem de donar per fet que alguns objectes són de color, fins i tot per a poder reconèixer i donar sentit al fet que percebem colors, aleshores crec que no podem acceptar el punt de vista "subjectivista" que manté que els objectes del món independent no són realment de color i que els colors dels objectes depenen del tipus de percepcions que els perceptors d'aquests objectes tindrien en determinades circumstàncies. Qui defense aquest punt de vista "subjectivista" hauria d'admetre que la gent veu colors i creu que els objectes són de color. Però, si el meu raonament és correcte, aquest teòric hauria 
de pressuposar que alguns objectes són de color, fins i tot a l'hora d'admetre els fets de la percepció i les creences humanes que la seua teoria pretén explicar. En acceptar la conclusió "subjectivista", aquest teòric seria incoherent en creure tot allò que ha de creure per poder assolir i defensar aquesta conclusió.

Deixant de banda, de moment, la qüestió dels colors de les coses, m'agradaria tornar finalment al judici que diu que "tots els valors són subjectius". Quin és el veritable suport d'aquesta idea? Per què és una idea que no sols s'accepta àmpliament, sinó que, pel que sembla, també resulta força convincent per a molta gent? Crec que, en part, és per les raons ja esmentades en l'explicació dels arguments de Hume. Hem vist que avaluar o valorar una cosa com a millor que una altra és prendre la que podem anomenar una actitud "pràctica", "productiva" o "potencialment activa" en favor d'una cosa i en detriment de les rivals. Si algú té aquesta actitud envers certa cosa, està o estaria inclinat o disposat a actuar o jutjar en favor d'aquesta cosa en les circumstàncies apropiades. Si una persona no s'ha vist mai impel.lida a actuar de la manera com afirma que prefereix actuar, hauríem de jutjar que realment aquesta persona no subscriu l'actitud valorativa en qüestió. La no realització reiterada d'una acció quan tenim l'oportunitat de realitzar-la resta molta credibilitat al fet que subscriguem les actituds valoratives que diem que subscrivim.

Això sembla correcte respecte dels judicis o les preferències valoratives, en contraposició amb les creences sobre qüestions de fet. En aquest segon cas, pel que sembla, és possible romandre completament indiferent. Però, ja que no pot haver-hi per part de l'agent una acció intencional sense una avaluació o preferència entre els diferents cursos d'acció, fer certa cosa per una raó requereix considerar que un curs d'acció és millor que un altre. Per tant, un agent que actua intencionalment no pot ser completament indiferent a tots els possibles cursos d'acció. Això es podria expressar dient que, si els agents actuen intencionalment o per alguna raó, han de voler fer certa cosa més que altres. Les volicions o els desitjos rauen al nucli de l'explicació de l'acció i, tal com ja vam veure, Hume pensa que hem de concebre les volicions o els desitjos com a sensacions o sentiments. Pensa que és l'única manera en què les actituds valoratives, $\mathrm{i}$ les volicions i els desitjos vinculats a aquestes actituds, podrien fer-nos actuar. La raó per si mateixa, o el mer descobriment de la veritat, sense l'"addició" d'una actitud "activa", diu Hume, és "completament impotent" a l'hora de generar una acció. Les úniques forces "actives" o "productives" són les sensacions o els sentiments; res més no ens pot fer actuar.

He dit que el veritable origen del judici "tots els valors són subjectius" és la idea segons la qual les sensacions, els sentiments o les passions són necessàries per a totes les actituds avaluatives. Siga quin siga el valor de les coses o de les accions possibles per a una persona, aquest valor sembla "raure" només en 
les sensacions, els sentiments o les passions que els éssers humans actius tenen envers determinats objectes o cursos d'acció. Però ara hem de preguntar-nos si aquesta és, de fet, una descripció precisa de la manera com realment pensem i avaluem les coses que fem i que ens importen. ¿¿Realment pensem que l'existència d'una bona raó perquè una persona faça una determinada cosa, o no, depèn de les sensacions, els sentiments o les actituds d'aquesta persona envers la cosa? $¿ \mathrm{O}$ pensem que pot haver-hi raons per a fer certa cosa i que hom pot fer certa cosa per raons que són independents dels sentiments, els desitjos o les inclinacions, d'aquesta o de qualsevol altra persona? Aquesta és una qüestió que fa referència a la idiosincràsia de les nostres actituds valoratives i del seu tarannà.

Plantegem ara l'assumpte com una simple qüestió de fets que podem observar. ¿'Sabem del cas d'algú que haja actuat d'una manera determinada simplement en reconèixer quelcom com una raó per a actuar d'aquesta manera? Per exemple, ¡succeeix mai que algú es veu impel.lit a socórrer a un nen que veu sol i ofegant-se a la mar, o que algú console un amic afligit? Tots coneixem persones, espere, que actuarien immediatament en aquestes circumstàncies. Hi succeeix. Segons sembla, aquestes persones presten ajut perquè veuen el perill que amenaça el nen, o l'angoixa de l'amic, com a raons per a actuar com ho fan. Prenen allò que saben de la persona en qüestió com una raó per a actuar d'una manera determinada, i actuen en conseqüència. Per a les persones que es veuen motivades a actuar així, i que actuen així amb regularitat, no sembla que calga res més perquè actuen. Veuen el que creuen identificar com una raó per a actuar i, quan fer-ho és possible i adequat, actuen de la manera requerida. També sembla que aquestes persones consideren que el fet que el benestar del nen estiga en perill, o que l'amic estiga afligit, és una raó per a actuar d'aquesta manera, independentment de si una altra persona ho consideraria així, o de si alguna altra persona actuaria de la mateixa manera.

Per descomptat, no tota persona que veja que el nen està en perill o que l'amic està afligit actuarà d'aquesta manera. Veure un nen en perill o un amic en dificultats no és una condició suficient per dur a terme la acció de prestar ajut. Allò que fa que una persona actue així depèn de qui és aquesta persona, $\mathrm{o}$ de quin tipus de persona és, de quines són les raons que considera per a actuar de certa manera i de si és el tipus de persona que tendeix a actuar per unes raons com aquestes. No tothom és igual, en tots aquests respectes. No obstant això, per a aquelles persones que consideren que una raó per a actuar és quelcom que trobem veritable en unes circumstàncies determinades, i que actuen en conseqüència, no hi ha res més que semble necessari per a explicar per què actuen com actuen. Reconeixen el que consideren una raó i immediatament actuen d'acord amb aquesta raó.

Arribats en aquest punt, és molt temptador insistir en el fet que les 
persones que presten ajut d'aquestes maneres ho fan només perquè volen ferho, a causa dels seus desitjos. Això és cert, però en si mateix aquest no és un argument a favor del "subjectivisme". Per descomptat, les persones que s'hi preocupen fan el que fan per voluntat pròpia. Volen auxiliar al nen o a l'amic perquè veuen el perill o l'angoixa com una raó per a prestar ajut. Són volicions o desitjos generats pel reconeixement de la condició de l'infant o de l'amic. Tenen el que podríem anomenar un desig "motivat" o que "resulta d'una raó" 6 per a fer el que fan. La volició o el desig que els motiva a actuar com actuen la genera el reconeixement de quelcom relatiu a la condició de l'infant o de l'amic; una cosa que, per a ells, constitueix una raó per a actuar d'una manera determinada.

Pel que fa a alguns tipus de desitjos o volicions, senzillament sembla que els trobem en nosaltres, acompanyant-nos, sense haver meditat sobre ells de cap de les maneres. Aquests desitjos simplement sorgeixen en nosaltres i la seua sola presència sembla donar-nos una raó per a fer certa cosa que abans no teníem cap raó per a fer. Em trobe assedegat i vull beure. Això podria anomenar-se un desig "no motivat" o que "crea una raó". La set em dóna raons per a beure. Per contra, un desig "motivat" o que "resulta d'una raó" es presenta quan un agent vol actuar d'una manera determinada perquè reconeix certa cosa com una raó per a fer-ho; reconeix la conveniència, la rectitud o el valor de l'acció, ja siga en els seus resultats o en el mateix fet de dur-la a terme. Aquests tipus distintiu de volicions, desitjos o actituds, motiven l'agent a actuar perquè aquest creu alguna cosa sobre l'acció: quelcom que considera que és una raó per a actuar.

Allò que accepta un agent d'aquest tipus, i que el mou a actuar, es podria anomenar pensament o judici "avaluatiu" sobre l'acció. La idea que existeix una raó per a fer tal i tal cosa, allò que cal fer o que és correcte en una situació determinada, no és simplement una creença en el que Hume anomena una "qüestió de fet". És una qüestió d'avaluació. Tanmateix, que l'agent avalue així l'acció, que accepte el caire "avaluatiu" de la seua creença relativa a l'acció, no implica que el valor que veu en l'acció, o que pensa que aquesta posseeix, depenga de cap de les maneres de l'actitud avaluativa que realment mantinga respecte a l'acció. L'agent pren aquesta o aquella cosa com una raó per a actuar d'una determinada manera i la pren com una raó amb independència de si algú, inclòs ell mateix, creu que és una raó, o no.

Fet i fet, aquest és un aspecte comú a tot pensament, fins i tot quan no hi ha avaluacions implicades. Per exemple, que hi haja muntanyes a l'Àfrica, o no,

\footnotetext{
${ }^{6}$ En l'original, "motivated desire" i "reason-following desire", que contrasten respectivament amb "unmotivated desire" i "reason-producing desire", que apareixen a continuació.
} 
és una qüestió de fet que és bastant independent del fet que algú crega que hi ha muntanyes allà. Per tant, algú que creu que hi ha muntanyes a l'Àfrica creu una cosa que s'escau, o no, independentment de si aquesta persona o qualsevol altra realment ho creu o no creu absolutament res. Que una persona tinga una certa creença, o no, en general, és irrellevant per a la qüestió de si allò que la persona creu és així o no. Si traslladem aquesta idea al pensament avaluatiu, i crec que ho podem fer, aleshores allò que una persona pensa quan pensa que hi ha una bona raó per a fer certa cosa és quelcom que s'escau o no independentment de si aquesta persona, o qualsevol altra, avalua l'acció d'aquesta manera, o de si realment experimenta un sentiment o altre, pel que fa al cas.

Per exemple, qui creu que l'esclavitud és dolenta o deplorable pot pensar que ho és independentment de si algú més ho creu. Allò que creu —que l'esclavitud és dolenta o deplorable- és una cosa que pot ser així fins i tot si tothom pensara que l'esclavitud és una idea meravellosa (excepte, potser, els esclaus). Per descomptat, una persona que condemna l'esclavitud en té aquesta valoració particular, però allò que creu (que l'esclavitud és dolenta) és independent del fet que aquesta o alguna altra persona avalue l'esclavitud de la mateixa manera, o que tendesca a experimentar un sentiment o altre envers l'esclavitud. Sens dubte, les accions que considerem dolentes o deplorables ens fan sentir d'una certa manera, però aquests sentiments no serien possibles si no prenguérem les actituds avaluatives que prenem envers les coses que ens fan sentir d'aquesta manera.

Així doncs, podem convenir que els judicis valoratius són essencials per a l'acció intencional. Per a comprendre que els éssers humans actuen moguts per certes raons, hem d'atribuir-los algunes actituds avaluatives. Però no hi ha judicis valoratius equivalents o reductibles a cap de les anomenades "qüestions de fet", que no tinguen implicacions avaluatives. Per tant, la concepció de les actituds avaluatives que acceptem, o atribuïm a altri, no pot construir-se exclusivament a partir dels anomenats materials "factics" o no avaluatius de què puguem disposar. El caràcter distintiu d'aquests judicis avaluatius és irreductible a quelcom purament factic i no avaluatiu. Els judicis impliquen la idea que hi ha quelcom que ens inclina a fer o a creure una cosa determinada o que constitueix una raó per a fer-la o creure-la. Tots tenim la capacitat de copsar judicis d'aquest tipus. La nostra concepció d'aquests judicis està essencialment implicada en la comprensió que tenim de nosaltres mateixos, i dels altres, com a pensadors $i$ agents que creuen i actuen per raons. No ens podríem concebre sense aquests judicis. De fet, crec que no podríem pensar res en absolut si no poguérem reconèixer que una cosa que creiem és una raó per a creure'n una altra. I el mateix val per a actuar intencionalment i per a fer coses per raons.

La meua proposta afirma, doncs, que tenir certes actituds avaluatives en- 
vers nosaltres mateixos és essencial per a comprendre i reconèixer que els altres són agents amb actituds avaluatives $i$, per tant, és essencial per a actuar i creure coses d'acord amb raons. Si això és així, trobe que ningú podria arribar conscientment a la conclusió metafísica que les raons o els valors pels quals entenem que actuen les persones són tots "subjectius" i depenen essencialment de les experiències o sentiments dels agents. Per a poder creure que hem arribat a una conclusió "subjectivista" d'aquest tipus sobre les actituds avaluatives per les quals actuem les persones, caldria mantenir certes actituds avaluatives sobre nosaltres mateixos, i, per tant, no podríem concebre aquelles actituds com a essencialment dependents dels sentiments, els interessos o les actituds de cap persona.

Aquesta conclusió sobre els judicis avaluatius, a la qual vaig de dret, és paral-lela a la conclusió que vaig plantejar sobre les creences relatives als colors de les coses. No crec que una concepció "subjectivista" d'aquestes creences siga acceptable, si volem evitar la incoherència, en cap dels dos casos. Però tot i que crec que ningú podria acceptar coherentment cap d'aquestes posicions "subjectivistes", és important adonar-se que això no implica que el "subjectivisme" relatiu als valors o als colors de les coses siga simplement fals. És a dir, no implica que una concepció metafísicament "objectivista" de les creences sobre els valors o els colors de les coses haja de ser, en canvi, vertadera.

Encara que el que he plantejat siga correcte, no podem concloure que hàgem descobert que el "subjectivisme" s'equivoca i que, al món tal com és independentment de nosaltres, els objectes siguen en realitat de color i que certes accions siguen efectivament millors o pitjors que altres. Com a màxim, podem deduir que una concepció "subjectivista" dels colors o dels valors de les coses no és acceptable de manera coherent. Pot ser que això no siga tot el que podíem esperar, però és alguna cosa.

Vull fer un últim comentari sobre els valors, en particular. No hi ha res en tot el que he dit que implique que, quan avaluem les coses tal com ho fem - fins i tot si pensem que els nostres judicis són independents del que ningú en pense o senta—, hàgem arribat així a la veritat definitiva sobre el cas, i que qualsevol persona que hi discrepe haja d'estar equivocada. No tenim cap garantia respecte al coneixement o a la veritat de les afirmacions valoratives que fem, fins i tot quan hi parem més esment. Tampoc no hem de creure que no es poden produir més desacords. Sempre podem qüestionar si allò que pensem que és de tal manera és realment així, no sols respecte de les avaluacions, sinó també respecte de les anomenades qüestions de fet. Sempre podem plantejar objeccions, però, per descomptat, no sempre tenim motius reals per a discutir seriosament. ¿Hi ha realment muntanyes a l'Àfrica? Només algú que no sàpiga res del món, o que no s'ho haja plantejat mai, podria realment 
dubtar-hi. Però podem dir el mateix de moltes preguntes avaluatives. ¿És el fet que un nen estiga ofegant-se tot sol a la mar una raó per a socórrer-lo? Qui hi podria dubtar seriosament? Per descomptat, no totes les preguntes avaluatives poden contestar-se amb tanta facilitat. Però moltes qüestions purament factiques tampoc no es poden respondre amb la mateixa facilitat que la de les muntanyes a l'Àfrica.

Crec que el "subjectivisme" té un origen comprensible. Fer afirmacions valoratives ens fa vulnerables al desacord o a la disputa, i sovint sembla que no hi ha manera de resoldre la qüestió d'una vegada per totes. Quan això s'esdevé sembla que no hi ha cap alternativa que ens faça avançar, cap a un examen més detingut i una avaluació més subtil de les raons favorables i desfavorables. I molta gent se sent profundament incòmoda amb el que sembla ser una indeterminació que no té uns límits precisos. Tot plegat, sembla que ens quedem sense una comprensió satisfactòria de què hem de fer o per quines raons hem de fer-ho. Stricto sensu, el "subjectivisme" manté que no existeix cap fet pel qual una cosa es constituesca en raó per a pensar o actuar de determinada manera. Això reforça la idea segons la qual que un agent actue com actua no s'explica realment pel que ell denomina el seu reconeixement de quelcom com una raó per a fer-ho. Ens sembla que necessitem alguna cosa més per a poder explicar per què les persones fan allò que fan.

Si insistim una mica més, la persona que considera que el perill que amenaça al nen és una raó per a socórrer-lo podria dir més coses sobre per què fa allò que fa. Podria dir que pren el perill del nen com una raó per a actuar perquè creu que les lesions o la mort d'un nen són una cosa "terrible", "deplorable", o potser "una de les pitjors coses que poden succeir". Aquesta explicació dels seus motius no deixa d'expressar-se, i és inevitable, en termes certament avaluatius. És per això que crec que molta gent considera que això no explica realment per què l'agent fa allò que fa; serien, diguem-ne, només "judicis de valor".

Però els termes avaluatius són els únics mots que tenim per avaluar els objectes o les accions que prenem en consideració. No és possible eliminar per complet les maneres de pensar avaluatives reduint-les a alguna cosa no avaluativa. No tenim més opció per explicar les nostres maneres de pensar distintivament avalautives que per mitjà de l'ús d'alguns dels mots avaluatius que ja emprem amb destresa. Només podem explicar els nostres pensaments avaluatius en termes avaluatius. He defensat que els judicis avaluatius són essencials per a actuar com ho fem i per a reconèixer les accions intencionals dels altres com a part del món on vivim. Per descomptat, no se'n segueix que els judicis avaluatius que fem siguen veritables. Però crec que sí que se segueix que no podem mantenir coherentment que cap dels nostres judicis avaluatius 
siga veritable o que tots els valors a què donem suport depenguen només de les sensacions, els sentiments o les passions no avaluatius dels subjectes humans.

En aquestes conferències he tractat de ressaltar que, si tenim una explicació ferma i precisa de com pensem el món —i sobre el que hi percebem, hi sentim i hi creiem-, podem veure que l'única cosa que faria atractiu el "subjectivisme" és la defensa d'una concepció molt restringida del contingut de les experiències $\mathrm{i}$ els sentiments que tenim al nostre abast. Amb la bellesa i la causalitat trobàrem que ni tan sols podíem identificar els sentiments o les experiències en qüestió sense tenir ja prèviament la idea de bellesa o de causalitat que apliquem al món en aquests mateixos judicis. Semblava que el "subjectivisme" prometia més en el cas dels colors i dels valors. Però allò que creiem sobre els colors dels objectes del món semblava massa estretament implicat en la nostra comprensió de les percepcions de color perquè puguem considerar que aquestes percepcions són res més que sensacions de determinats tipus. I el fet de prendre certes consideracions com a raons per a actuar de determinada manera també semblava estar massa estretament implicat en què volem i com decidim actuar perquè puguem entendre les voluntats i els desitjos que tenim com a meres sensacions o sentiments que, en alguna mesura, ens menen a l'acció.

Si més no, pel que fa als tipus de creences que hem estat considerant, crec que no hem aconseguit prendre distància de totes les nostres experiències, sentiments i respostes, ni entendre-les per si mateixes, al marge de la nostra comprensió de com són realment les coses al món que ens envolta. Això comença a indicar-me que potser no podem posar-nos en la situació de plantejar-nos la mena de preguntes totalment isolades sobre la relació entre la nostra concepció del món i el món mateix que sembla que tenim esperança de respondre.

Potser, ara per ara, podem ja arribar a fer-nos una idea de per què això pot ser així. Crec que tenim la necessitat de fer-nos preguntes molt generals sobre el nostre lloc en el món del tipus que he estat examinant. I, en aquest punt, podríem estar una mica desanimats pel que hem aconseguit en aquest sentit. Però crec que reconèixer que tenim aquesta necessitat, alhora que ens fa avançar en la comprensió de per què no podrem satisfer-la mai, pot considerar-se, en si mateix, una observació reveladora sobre la condició humana. 
